\title{
The Influential Factors in the Job Motivation among Midwives as the Healthcare Providers in the Iranian Health Sector Evolution Plan
}

\author{
Pooneh Masoumi Ganjgah $^{1}$, Mehrnaz Geranmayeh ${ }^{2}$, Shima Haghani ${ }^{3}$
}

\begin{abstract}
Background \& Aims: Midwives play a key role in the delivery of care services to mothers and neonates in the health system. The provision of high-quality services by midwives has a great impact on the prevention of maternal and neonatal mortality and its consequences, as well as the empowerment of women. It has been recommended that countries expand their midwifery programs, maintain the highest global standards, and improve the environment where midwives could effectively address the needs of women and their families. To achieve these goals, it is essential to motivate midwives as high job motivation could promote their efficiency. Theorists consider several factors to be influential in job motivation, such as physiological needs, safety, social needs, respect, and self-actualization. In Herzberg's two-factor theory, the needs and stimuli that motivate employees have been listed, as well as the approaches through which they could be addressed in an organization. Numerous studies have assessed the influential factors in the job motivation of midwives in Iran based Herzberg's theory. Meanwhile, midwives in healthcare centers have exclusively focused on their job duties (i.e., care of women of the reproductive age, pregnant women, and neonates). It seems that some of the motivational dimensions proposed for midwives have been modified due to the changes in the job duties of healthcare midwives in the Health Sector Evolution Plan, in which all midwives have been regarded as healthcare midwives, their organizational position has changed, and they were obliged to provide non-specialized and non-midwifery services in addition to specialized midwifery services, such as care services for infectious and non-communicable diseases for all ages and genders. Since the influential factors in the job motivation of midwives have not been properly recognized after the Health Sector Evolution Plan, the present study aimed to determine the influential factors in the job motivation of midwives based on Herzberg's theory.

Materials \& Methods: This descriptive, cross-sectional study was conducted on 207 midwives employed in the health centers affiliated to Tehran University of Medical Sciences (TUMS), located in the south of Tehran, Iran during in October-December 2018. The participants were selected via stratified sampling. Since TUMS covers three health networks of the south, Islamshahr, and Shahreray, each health network was selected as a stratified rank. Based on the population of the midwives of each rank and considering an average of two midwives per each health center, 120 health centers (south $=60$ bases, Islamshahr $=25$ bases, Shahreray $=35$ bases) were selected using a random numbers table for sampling. Data were collected using the standard Herzberg questionnaire and two open-ended questions regarding job motivation and intention to continue the profession after the Health Sector Evolution Plan. The quantitative data were analyzed in SPSS version 16 using descriptive statistics (independent $\mathrm{t}$-test, analysis of variance, and Pearson's correlation-coefficient). In addition, the qualitative data were analyzed by content analysis.

Results: In the responses to the internal factors in Herzberg's job motivation questionnaire, the highest score belonged to the nature of the job (mean: $2.86 \pm 1.01$ ), and the lowest score belonged to recognition (mean: $2.10 \pm 0.93$ ). Among the extrinsic factors, the highest score belonged to the interactions of colleagues (mean: $3.99 \pm 0.76$ ), while the lowest score belonged to salary and income (mean: $1.65 \pm 0.94)$. Furthermore, work experience prior to the Health Sector Evolution Plan $(\mathrm{P}=0.027)$ and work experience after the plan $(\mathrm{P}<0.001)$ had significant, inverse correlations with the internal factors. Work experience before the plan $(\mathrm{P}=0.016 ; \mathrm{r}=-0.167)$ and work experience after the plan $(\mathrm{P}=0.001 ; \mathrm{r}=-0.239)$ also had significant, inverse correlations with the internal
\end{abstract}

\footnotetext{
1. Department of Reproductive Health, School of Nursing and Midwifery, Tehran University of Medical Sciences, Tehran, Iran

2. Department of Reproductive Health, School of Nursing and Midwifery, Tehran University of Medical Sciences, Tehran, Iran (Corresponding author) Tel: 09122182811 Email: geranmay@tums.ac.ir

3. Biostatistics, Nursing Care Research Center, Iran University of Medical Sciences, Tehran, Iran
} 
factors, so that increased age and work experience before and after the plan led to the reduction of the mean scores of these factors. In addition, employment status had a significant association with the internal factors $(\mathrm{P}=0.004)$, so that the mean score of the internal factors in the corporate midwives was significantly higher than the formal and contractual midwives. Significant associations were observed between the work experience before the plan $(\mathrm{P}=0.037)$ and work experience after the plan $(\mathrm{P}<0.001)$ with the external factors. In addition, work experience before the plan $(\mathrm{P}=0.036$ and $\mathrm{P}=-0.146)$ and work experience after the plan $(\mathrm{P}=0.036$ and $\mathrm{P}=-0.146)$ had inverse, significant correlations with the external factors, and the increment in these variables led to reduced scores of the external factors. In addition, age had a significant correlation with the external factors $(\mathrm{P}=0.035)$, and the mean scores of these factors were significantly lower in the subjects aged more than 40 years compared to the mean scores of those aged less than 40 years. The majority $(81.1 \%)$ of the midwives who answered the open-ended questions about changing job motivation (first open-ended question) reported that their job motivation has decreased compared to before the implementation of the evolution plan, and more than half of the midwives who answered the open-ended question about the continuation of the job as a healthcare midwife were willing to quit. Conclusion: In general, the analysis of the responses to the open-ended questions indicated that low income, heavy workload, stress, and unrelated tasks to midwifery reduced job motivation and increased the tendency to quit in the healthcare midwives after the health evolution plan. Therefore, it is recommended that healthcare authorities attempt to enhance the motivation of midwives and guarantee the quality and maintenance of midwifery care by designing appropriate evaluation and motivational mechanisms, providing a payroll system based on workload (improving the external factors), defining the job position of family midwives in the health system as opposed to healthcare midwives, and the fundamental review of the job description and position of midwifery in the health system (enrichment of the midwifery profession). Furthermore, conducting research on the views and opinions of middle-range managers of the Health Sector Evolution Plan about staff motivation and the challenges in improving the quality of the healthcare services provided by midwives and healthcare providers could result in the inclusive assessment of the issues and challenges and adoption of comprehensive, practical, and effective strategies.

Keywords: Job Satisfaction, Midwifery, Healthcare Provider, Health System

\section{Conflict of Interest: No}

How to Cite: Masoumi Ganjgah P, Geranmayeh M, Haghani SH. The Influential Factors in the Job Motivation among Midwives as the Healthcare Providers in the Iranian Health Sector Evolution Plan. Iran Journal of Nursing. $2020 ; 33(125): 13-27$.

Received: 4 May 2020

Accepted: 3 Aug 2020 


\title{
عوامل مرتبط با انكيزه شغلى ماماها به عنوان مراقب سلامت در طرح تحول سلامت
}

\author{
يونه معصومى كَنجًَاه '، مهرناز تَر انمايه'، شيما حقانى
}

\begin{abstract}
جكيله
زمينه و هدف: ماماها نقش مهمى در ارائه خدمت به مادران و نوزادان در نظام سلامت دارند. انخحيزه شغلى بالا ميتو اند موجب ارتقاء بهره ورى آنان شود.

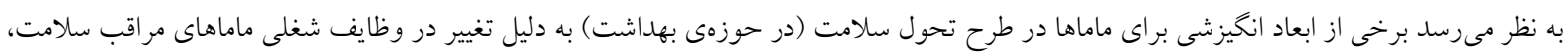

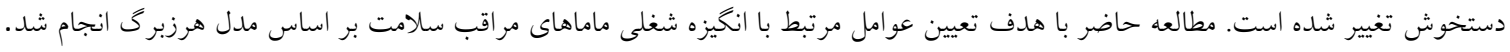

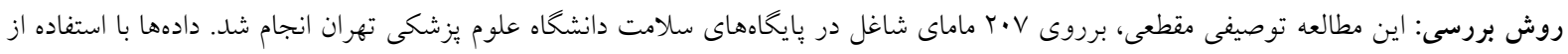

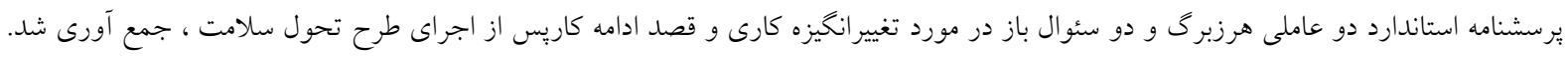

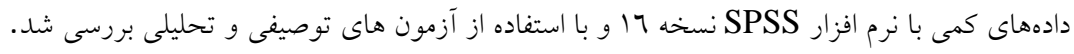

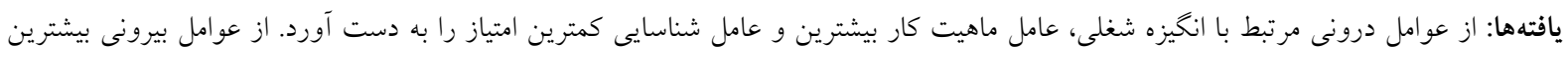

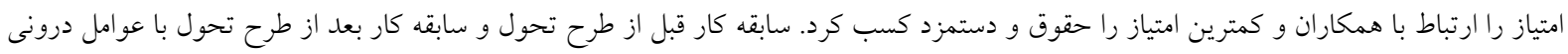

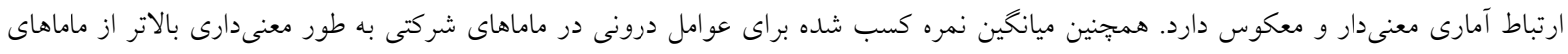

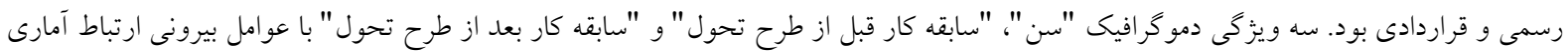

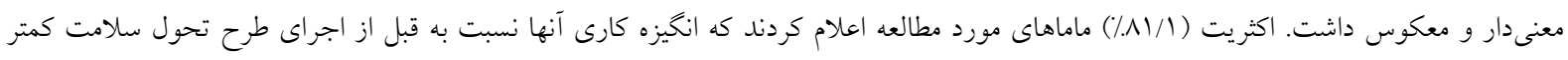

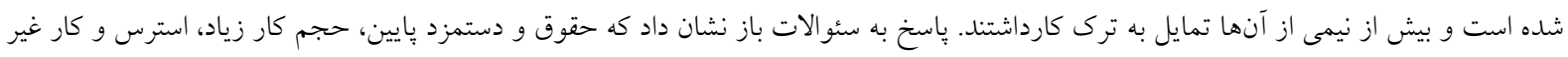

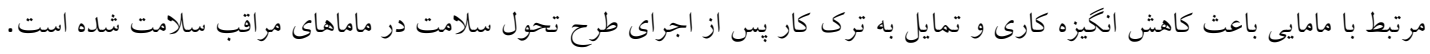

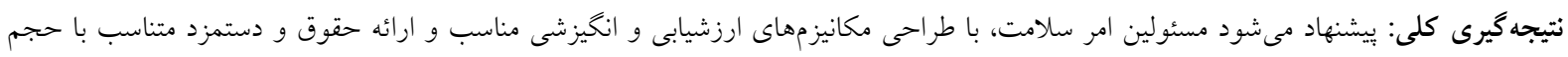

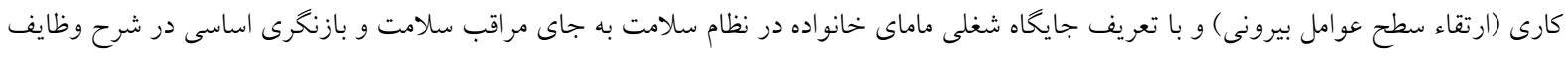

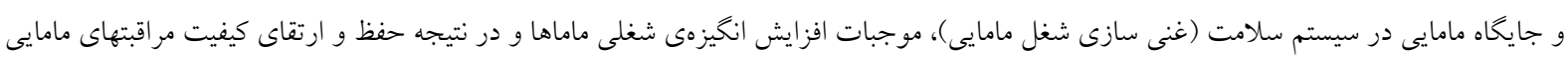
را فراهم آورند.

كليد وازهها: رضايت شغلى، مامايى، مراقب سلامت، سيستم سلامت تعارض منافع: ندارد تاريخ دريافت: تاريخ بذيرش: 99/0/1T

شماره

' ' ' تروه بهداشت بارورى و زايمان، دانشكده يرستارى و مامايى، دانشًاه علوم يزشكى تهران، تهران، ايران.

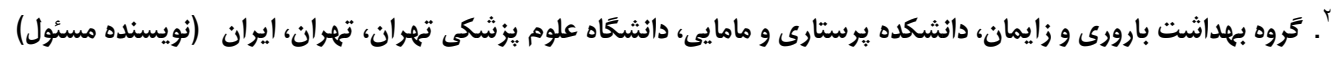


شغلى ماماها در ايران عمدتاً ميزان رضايت آنان را متوسط تا بايين كزارش كرده است (1). عوامل مختلفى مىتواند با انخيزش شغلى ماماهن كردا مرتبط

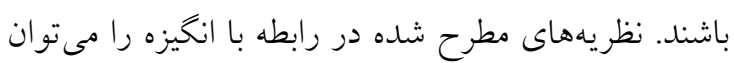

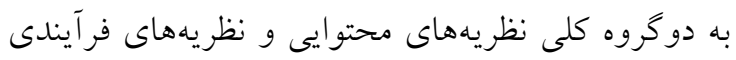

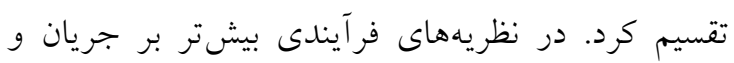

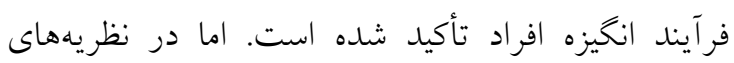

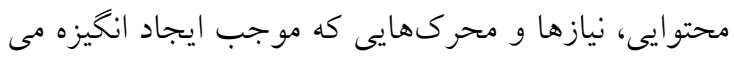

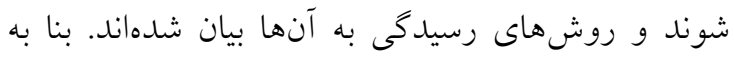

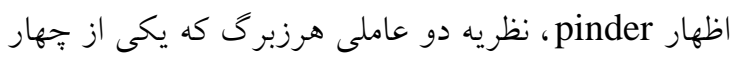
نظريه محتو ايى است، بيش از ساير نظريه ها مورد موشكافى

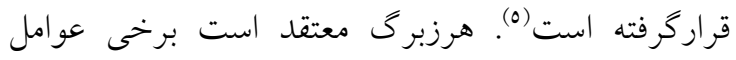
وجود دارند كه افراد در اثر فقدان آنها، احساس رضايت فردئل

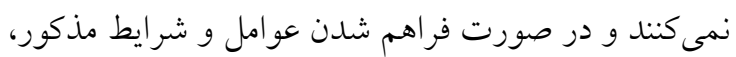
احساس نارضايتى آنان كاهش مى يابد ولى ارضاى درى آنها

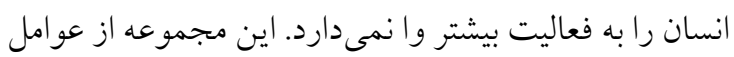
را عوامل بيرونى مىنامند كه شامل: خط مشى و مقررات

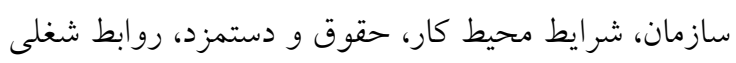

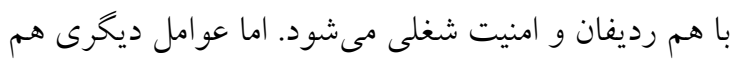

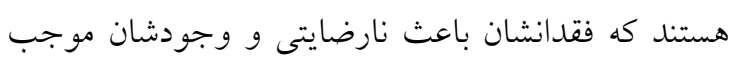

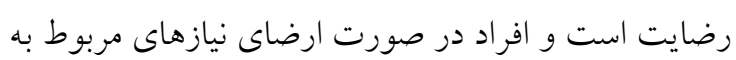
آن برانخيخته مىشوند و اين انخيزه سبب سخت كار كردن

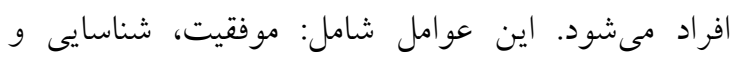

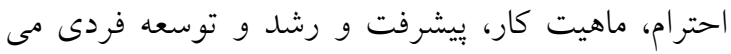
شود كه به آنها عوامل درونى مى گويند (r).

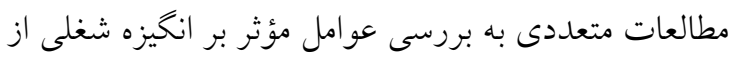

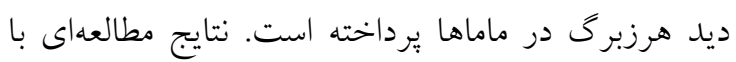
هدف تعيين انخيزش شغلى ماماهاى استان خوزستان و عوامل مرتبط با آن نشان داد كه در بين عوامل بيرونى

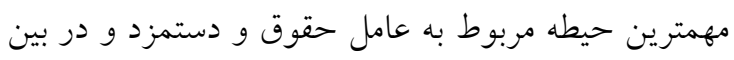

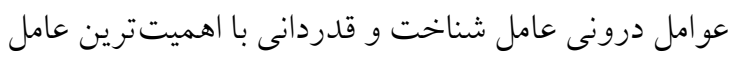
بود (rا). در مطالعهى ديخرى از نظر كاركنان بيمارستانهاى

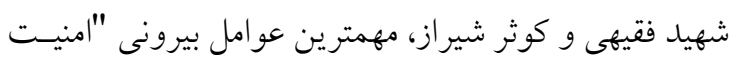

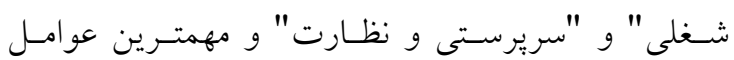

\section{مقدمه}

هم اكنون بيش از ...... ماما در سيستم بهاشتى درمانى ايران مشغول خدمت هستند(1). ماماها در سيستم ارائه خدمات بهداشتى در دنيا و ايران، وظيفه مراقبت از زنان، نوزادان و مادران باردار را به عهله دارند و به عنوان يكى از كروههاى مؤثر بر كيفيت ارائه خدمات بهداشتى و مراقبت، شناخته مىشوند (r.r). به منظور بيشخيرى از مرگ مادران و نوزادان و عواقب آن و توانمند ساختن زنان كه همخى كليد دستيابى به اهداف توسعه يُايدار تا سال •ب.r مىباشند، توصيه شده كه كشورها برنامهاى مامائى خود را كسترش دهند، بالاترين استانداردهاى جهانى را حفظ نمايند و همجينين محيطى كه درآن ماماها بتوانند بطور مؤثر به نيازهاى زنان و خانوادهها بِاسخ دهند را ارتقاء دهند (ع). براى نيل به اين اهداف تأمين انخيزهى شغلى ماماها ضرورى به نظر مىرسد، زيرا عملكرد كاركنان در كنار نياز به مهارتهاى لازم، تابعى از انخيزه آنهاست (0). ميل يا اراده انجام كار يا همان انخيـزه شغلى، عامل اساسى در ايجاد تلاشها و فعاليتهـاى فرد و ثبات و تداوم آن فعاليتها در محيط كار است(7). نظريه يردازان عوامل متعددى را بر

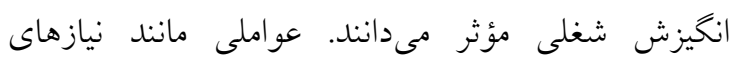

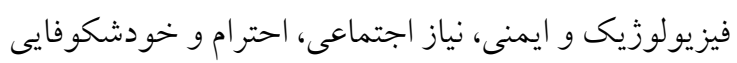

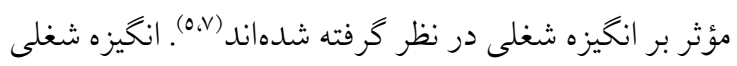
بالاى كاركنان و به تبع آن رضايت شغلى باعث ارتقاء كيفيت خدمات سازمان و مانعى براى ترى كار نيروها به

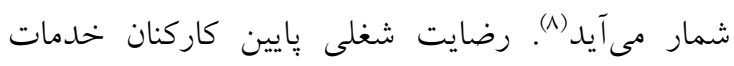
بهاشتى موجب كاهش كيفيت ارائه خدمات بهاشتى، كاهش رضايت ملدجويان و حتى آسيب جسمى و روحى نو كار كنان مى كردد (9). رضايت شغلى ماماها در نقاط مختلف جهان متفاوت است. به عنوان مثال يزّوهش انجام شده در سنخال رضايت شغلى ملى

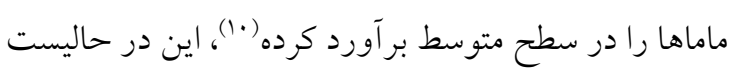
كه سطح رضايت شغلى ماماها در تركيه يايين كزارش شده

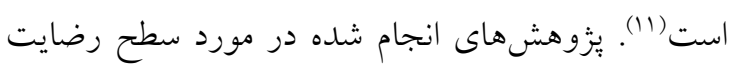


با توجه به اينكه طبق نظريه هرزبرگ عوامل فوق يعنى تغيير

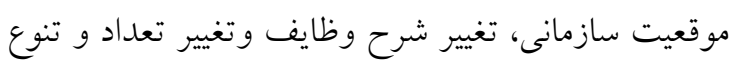

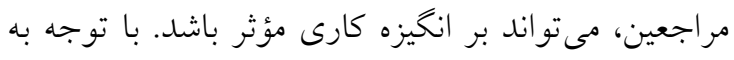

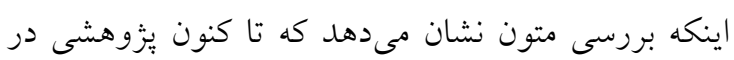

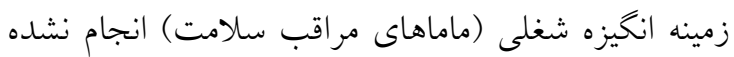
است، اين مطالعه با هدف تعيين عوامل مؤثر بر انخيزه

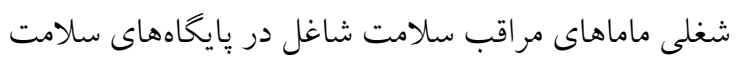

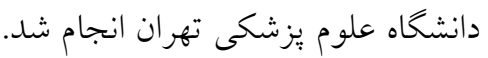

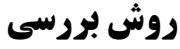
اين مطالعه مقطعى از نوع توصيفى، در مهرماه تا آذر ماه

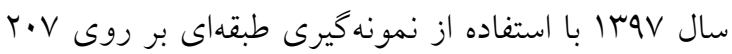
نفر از ماماهاى مراقب سلامت شاغل در بايخاههاى سلامت زير مجموعه دانشخاه علوم يزشكى تهران انجام شد. حداقل حجم نمونه لازم در سطح اطمينان (90\%) با دقت برآ آورد •• • و با توجه به مطالعات مشابه(10) كه انحر اف معيار را

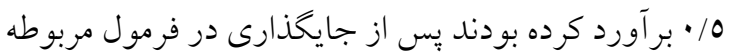
برابر با ..r نفر بدست آمد. با توجه به اين كه دانشخاه

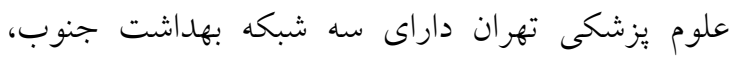

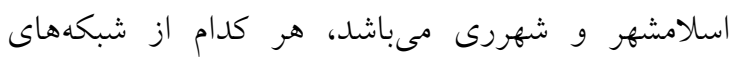
بهداشت شهررى، اسلامشهر و جنوب به عنوان يك طبقه انتخاب شدند. بر اساس تعداد جمعيت ماماها در هر كدام طبقات ياد شده و با توجه به اينكه به طور متوسط در هر

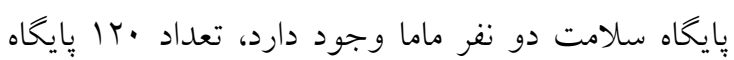

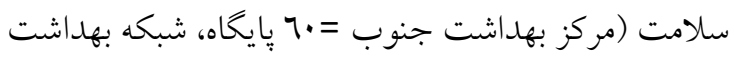

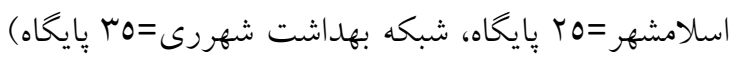

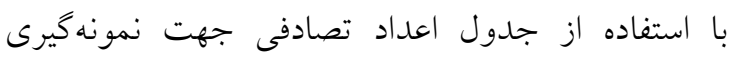

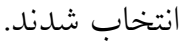
معيارهاى ورود به مطالعه شامل دارا بودن حداقل مدرى كاردانى مامايى و حداقل شش ماه سابقه كار در بايخاه سلامت و معيار خروج، تكميل ناقص يرسشنامه بود. پِ از بيان اهداف و كسب رضايت ماماهاى مراقب سلامت، يرسشنامها به صورت خودايفا تكميل شده و توسط

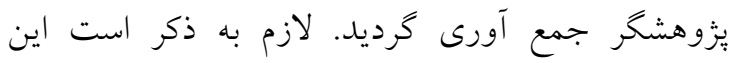

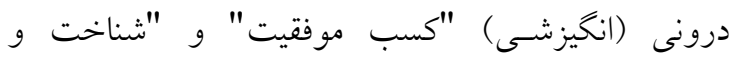
قدردانى" بود (ع). در يزووهشى در مورد عو امل اصلى مؤثر

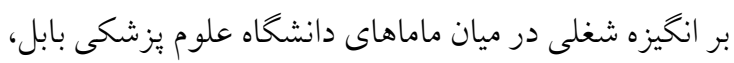

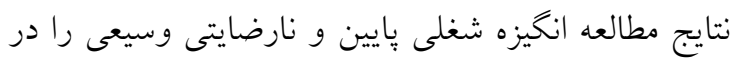

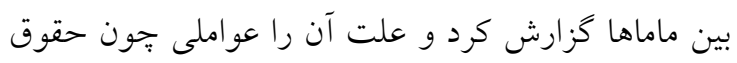
و مز ايا، مقررات سخت شغلى، فرصت هاى شغلى و مكانيزم

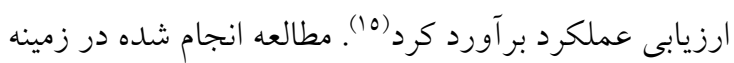

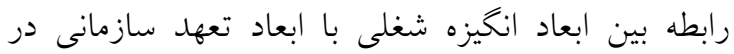
ماماهاى شاغل، نشان داد كه ابعاد ارتباطات، حقوق و دستمزد و ماهيت كار در تعهد ماماها اهميت ويزهاى دارد و توجه بيشتر به اين ابعاد مى تواند در افزايش انخيزه و تعهد سازمانى ماماها مفيد باشد (17). مطالعات فوق در حالى انجام شده است كه ماماها در مراكز

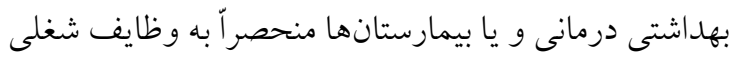

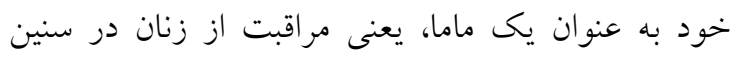

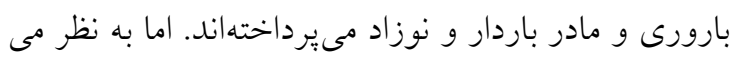

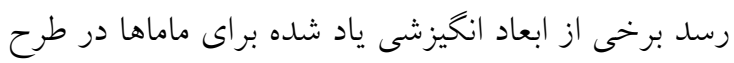

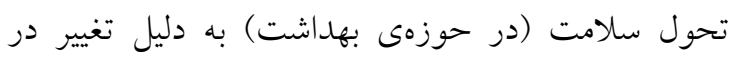
وظايف شغلى ماماهاى مراقب سلامت، دستخوش تغيير شده است. در سالهاى اخير و به دنبال اجراى طرح تحول سله

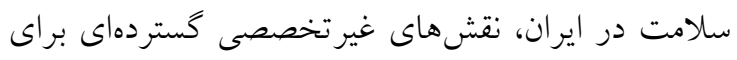
ماماهاى دركير در اين طرح تعريف شده است كه مى تواند

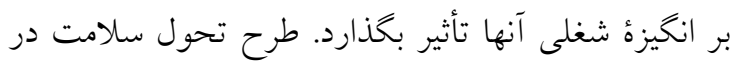

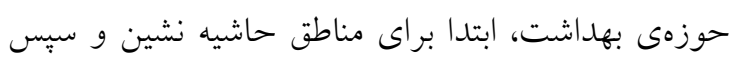

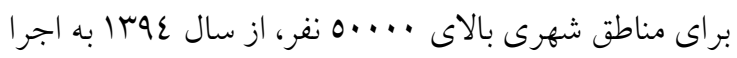

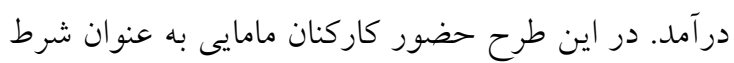

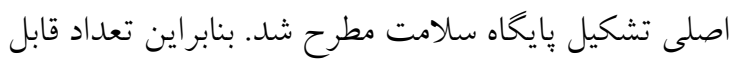
توجهى نيروى مامايى جذب و به ماماهاى شاغل در مراكز بهداشتى درمانى اضافه شدند. همهى اين ماماها تبديل به ماماهاى مر اقب سلامت شدند، موقعيت سازمانى آنها تغيير كرد و موظف شدند كه علاوه برخدمات تخصصى مامايى،

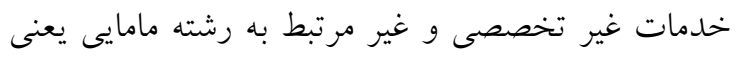

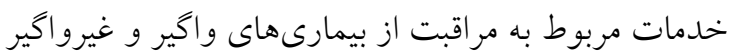

براى همه كروههاى سنى و جنسى را نيز انجام دهند ("). 
جهت تأمين اعتبار سؤالات باز، نظر •ا تن از اعضا هيئت

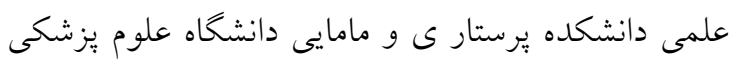
تهران در مورد سؤالات كسب شد و اعمال كرديل. هم جنين نتايج حاصل از تحليل سؤ الات باز توسط دو تن از

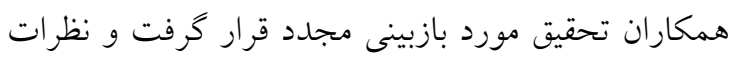

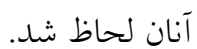

در بررسى حاضر بعد از جمع آورى دادههاى حاصل از

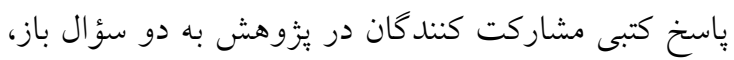

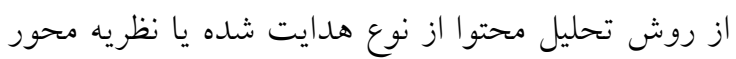

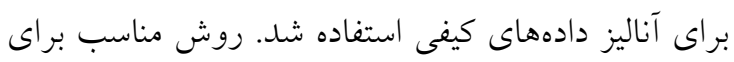
تحليل كيفى متون با استفاده از نظريه، روش تحليل محتوا كيفى هدايت شده يا نظريه محور، مىباشد كه در سال

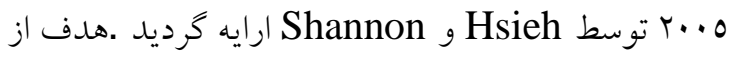
اين نوع تحليل، اعتبار بخشى يا توسعه يك جارجوب

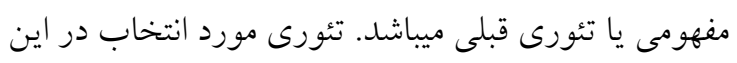

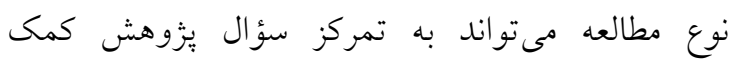

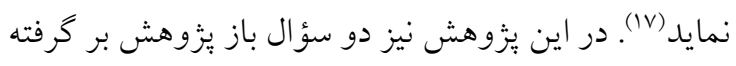

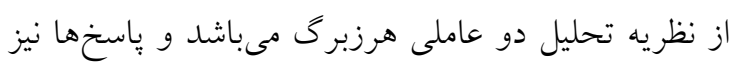
بر اساس تحليل محتواى هدايت شده آناليز شد.

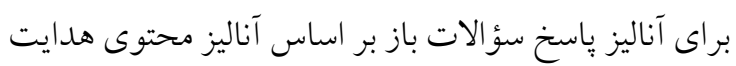

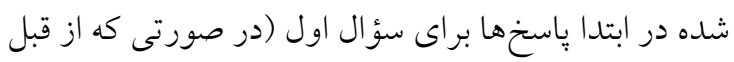

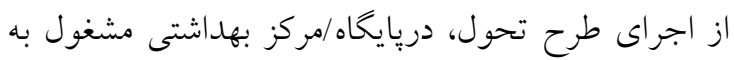

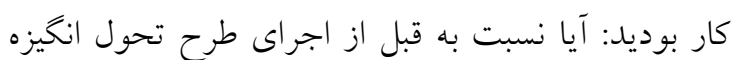

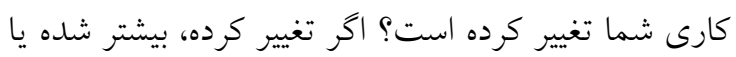

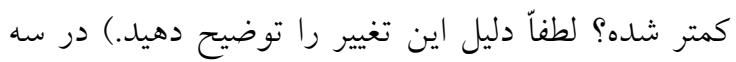
كروه كاهش انخيزه، تغيير نكردن انكيزه و افزايش انخيزه و

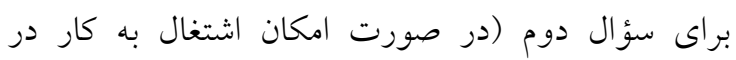

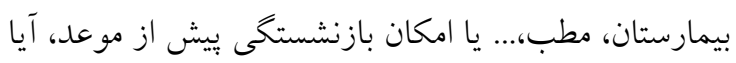
همجنان كار كردن به عنوان مراقب سلامت - ماما را ترجيح مى دهيد؟ لطفاً توضيح دهيد) در دو كروه قصد ادامه كار

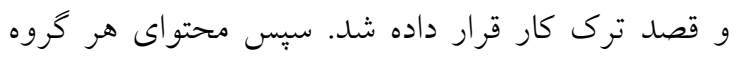
توسط دو نفر از اعضاى تيم تحقيق، به طور جداكانه كدبندى شده سبس موارد مشابه و متفاوت مشخص گر خرديد.

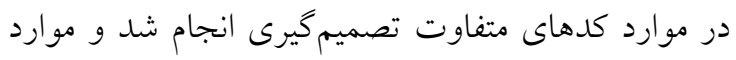

يُزوهش در دانشكده يرستارى و مامايى دانشخاه علوم

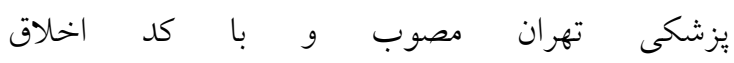
IR.TUMS.FNM.REC.1397.154 ثبت شده وان است.

ابزار بررسى، يرسشنامهاى شامل سه قسمت بود: قسمت

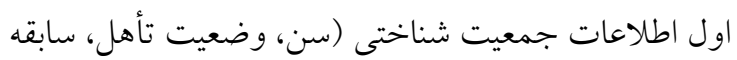

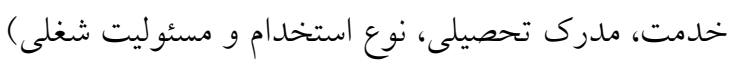

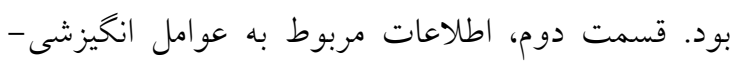

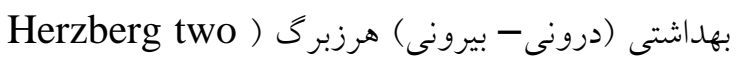
(-factor theory questionnaire در دو بعد عوامل درونى (موفقيت سه سؤال، بيشرفت دو

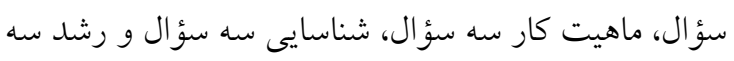

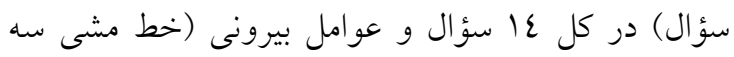
سؤ ال، ارتباط با همكاران سه سؤال، امنيت شغلى سه سؤ ال،

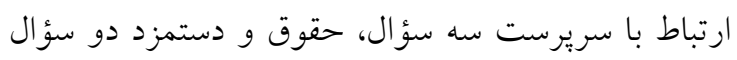
و شرايط كارى دو سؤال) در كل 17 سؤال بود. همه كويه

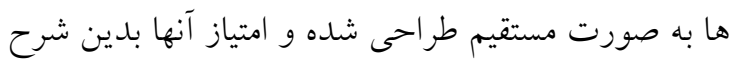

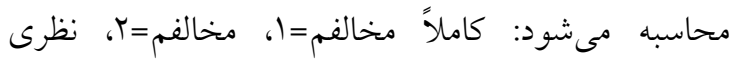

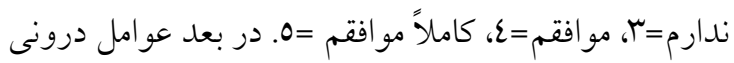

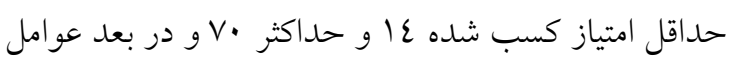

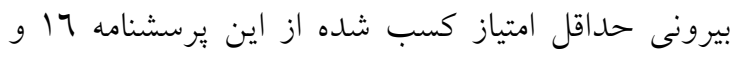

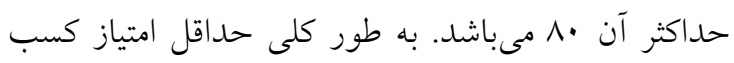

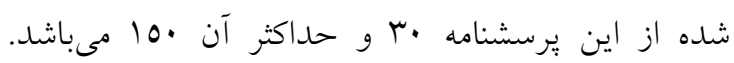

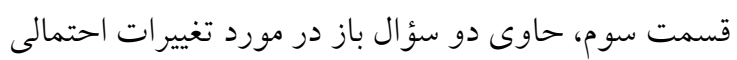

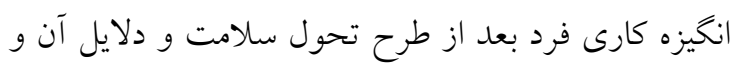

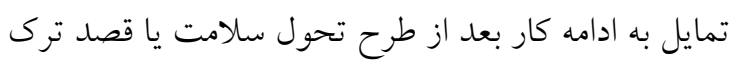

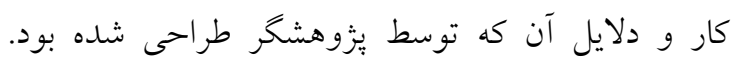

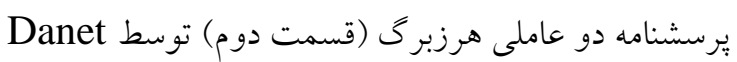

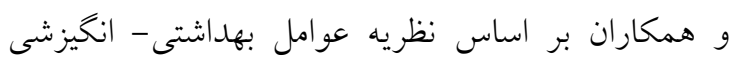

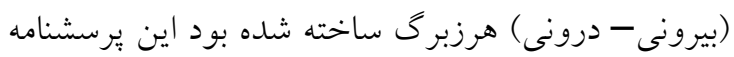

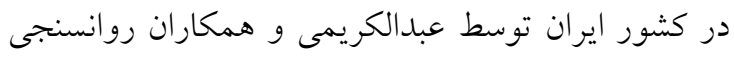

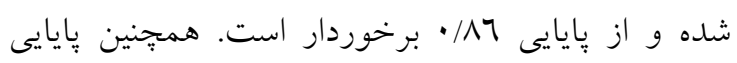
يرسشنامه هرزبرى در بزوهش رضايى صوفى و شعبانى نيز برابر با 97/ • اعلام شده است . 
استنباطى از آزمونهاى تى مستقل، آناليز واريانس و همبستخى بيرسون استفاده شد.

\section{يافتهها}

در اين مطالعه در مجموع •ع ب برسشنامه در اختيار نمونه

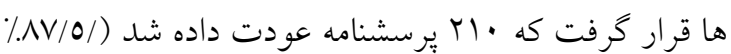

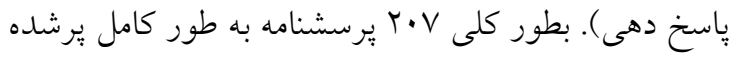
بود. سه برسشنامه به علت نقص در تكميل سؤالات مربوط به يرسشنامه هرزبرگ از مطالعه خارج شد.
اختلاف با مشاركت نفر سوم كه درامر تحقيق مشاركت داشت به توافق نزديك شد. در مجموع ·. . كد به دست آمد. كدهاى اوليه بر اساس تشابه و فراوانى طبقه بندى شده و با مشاركت اعضا تيم تحقيق طبقات نهايى استخراج شد. تحليل دادها توسط نرم افزار SPSS نسخه 17 به روش توصيفى و آمار استنباطى صورت گرفت. در آمار توصيفى از جدول توزيع فراوانى (براى متغيرهاى كيفى) و شاخص هاى عددى ميانگين و انحراف معيار بيشينه و كمينه (براى بررسى متغيرهاى كمى) استفاده شد. در بخش آمار

جدول شماره ا: مشخصات جمعيت شناختى ماماهاى مراقب سلامت شاغل در يايكاههاى سلامت دانشكًاه علوم يزشكى تهران و ارتباط

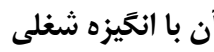

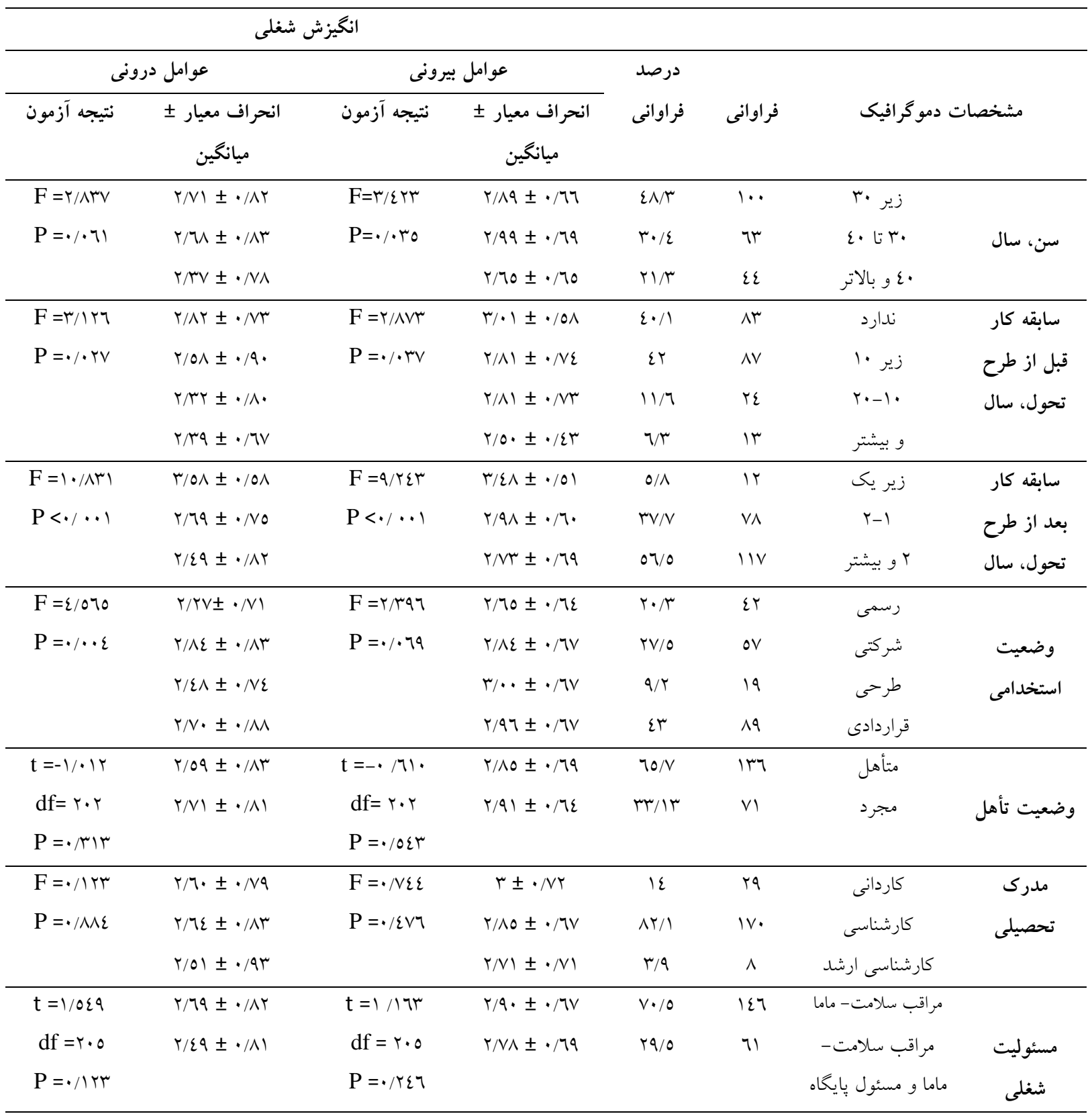


دو شفه نشاندهنده آن بود كه ميانخين نمره كسب شده براى

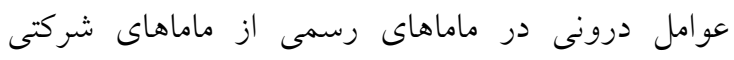
(p=•/・1)

$$
\text { صورت معنى دارى كمتر بود. }
$$

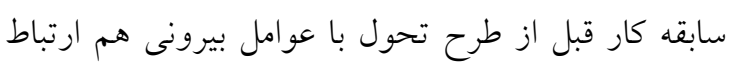
آمارى معنى دارى داشت (P=/rV) دو شفه نشان داد كه تفاوت آمارى معنى دارى بين سطوح سابقه كار قبل از طرح تحول وجود ندارد. ضريب همبستخى ييرسون نشان دهنده آن است بين عوامل بيرونى فئى

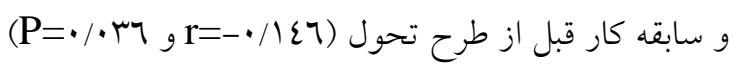

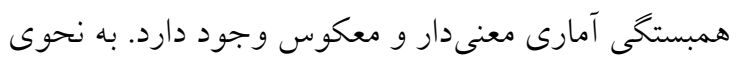

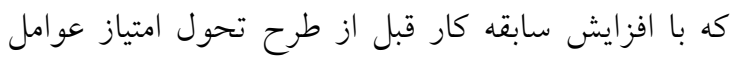

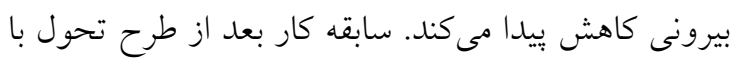

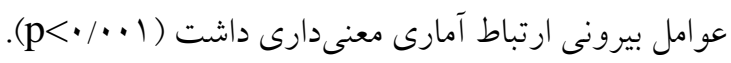

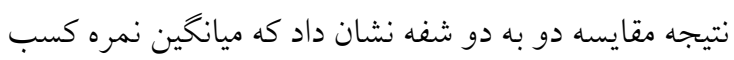
شده براى ماماهاى داراى سابقه كار دو سال و بيشتر به طور

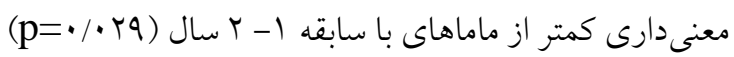

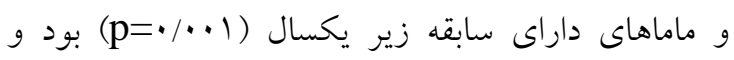

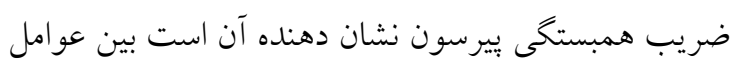

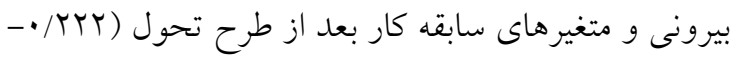

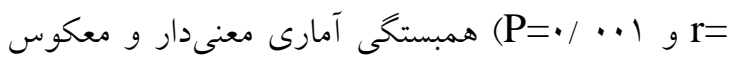

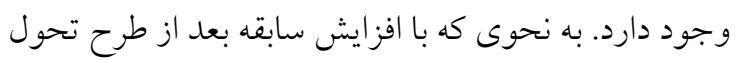

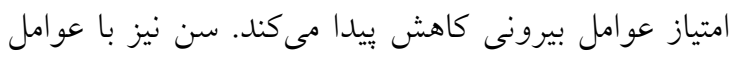

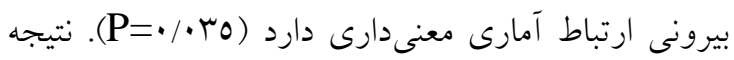

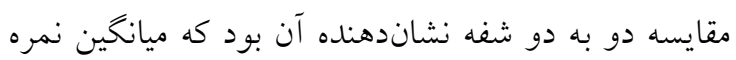
كسب شده در سن •ع سال و بالاتر به طور معنى دارى كمتر

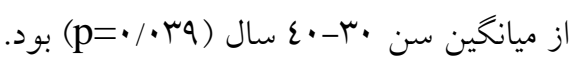

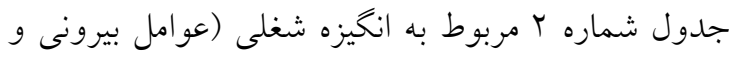

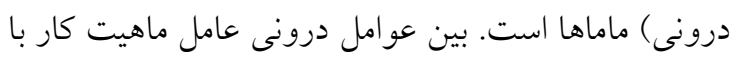

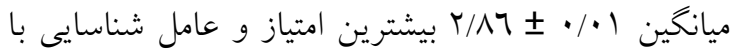

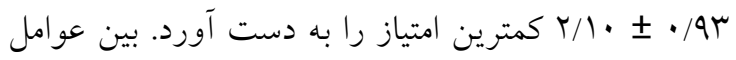

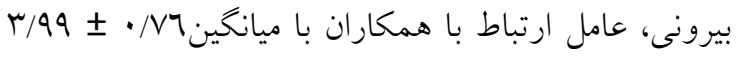

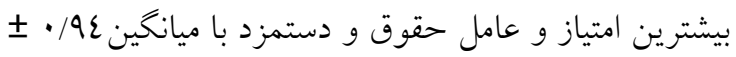

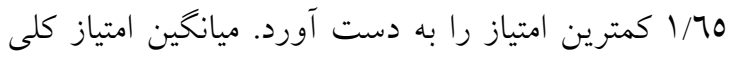

جدول شماره ا به بررسى مشخصات جمعيت شناختى

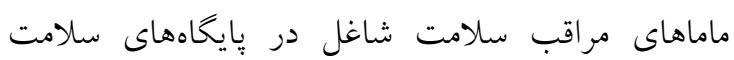

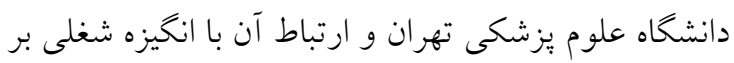

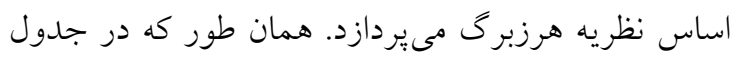

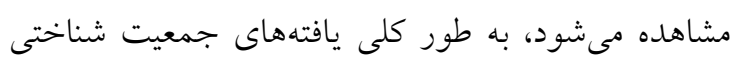

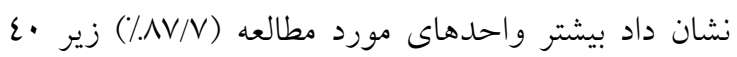

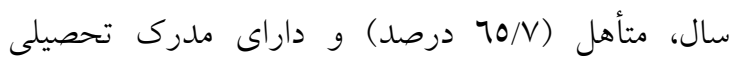

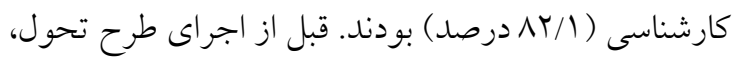

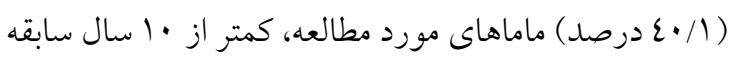

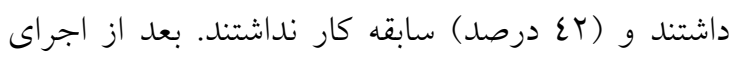
طرح تحول، بيش از نيمى از واحدهاى مورد مطالعه

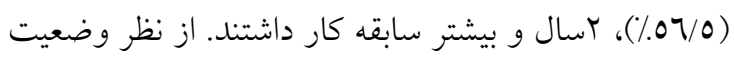
استخدامى بيشترين نوع استخدام مربوط به استخدام استهام قراردادى (Tع درصد) و بيشترين مسئوليت شغلى، مراقب

$$
\text { سلامت- ماما ( V V V درصد) بود. }
$$

سابقه كار قبل از طرح تحول باعو امل درونى ارتباط آمارى معنى دارى داشت (P=/rV) اختلاف معنى دارى بين سطوح را نشان نداد (0) (P> (P).

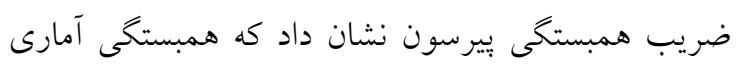

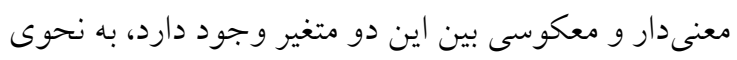

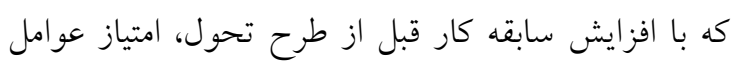

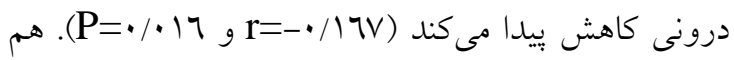
جنين عوامل درونى با سابقه كار بعد از طرح تحول رابطه

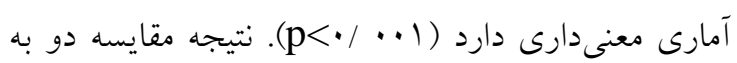

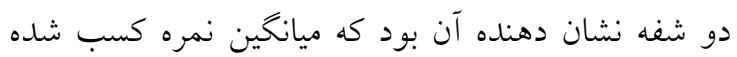
براى عوامل درونى در ماماهاى داراى زير يكسال سابقه كار

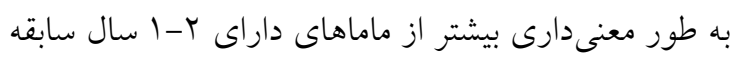

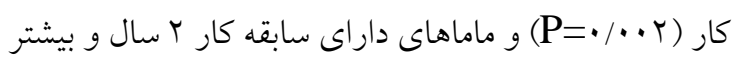
(p< بود. ضريب همبستكى بيرسون نشان دهنده

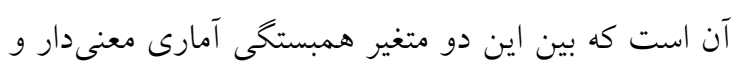
معكوس وجود دارد، يعنى با افزايش سابقه كار، امتياز

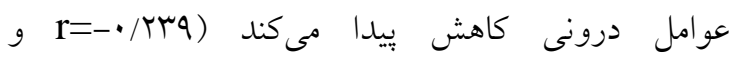

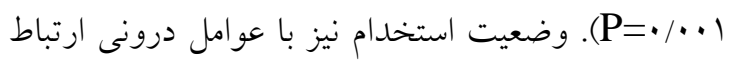

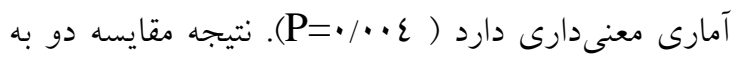


كلى عوامل بيرونى براى واحدهاى مورد مطالعه، Y/AV به عوامل درونى براى واحدهاى مورد مطالعه، بآ/ به دست دست آمل. كه از نمره ميانه ابزار يعنى لَّيايينتر بود. آمد. كه از نمره ميانه ابزار يعنى ب بايينتر است. ميانكين

جدول شماره r: توصيف عوامل درونى و بيرونى انكيزش شغلى در ماماهاى مراقب سلامت شاغل در يايكاههاى سلامت دانشكًاه علوم يزشكى تهران

\begin{tabular}{|c|c|c|c|c|c|c|c|c|c|}
\hline بر مبناى 0-1 & \multicolumn{3}{|c|}{ بر مبناى امتيازات } & \multirow{3}{*}{$\begin{array}{c}\text { حيطههاى عو امل } \\
\text { بيرونى (امتياز) }\end{array}$} & \multirow{3}{*}{ 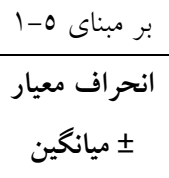 } & \multicolumn{3}{|c|}{ بر مبناى امتيازات } & \multirow{3}{*}{$\begin{array}{c}\text { حيطه داى عوامل } \\
\text { درونى (امتياز) }\end{array}$} \\
\hline انحر اف معيار & انحر اف معيار & بيشينه & كمينه & & & انحر اف معيار & بيشينه & كمينه & \\
\hline I ميانخين & I ميانگين & & & & & I ميانگين & & & \\
\hline$r / 79 \pm \cdot / \wedge r$ & $\Lambda / \cdot \vee \pm r / \varepsilon \Lambda$ & 10 & r & خط مشى & $r / 77 \pm 1 / \cdot r$ & $V / q \wedge \pm r / l$ & 10 & r & موفقيت \\
\hline$r / 99 \pm \cdot / V 7$ & $11 / 9 V \pm r / T q$ & 10 & r & 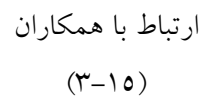 & $T / A T \pm 1 / \cdot V$ & $0 / \nearrow \varepsilon \pm T / / \varepsilon$ & 1. & r & $\begin{array}{l}\text { بيشرفت } \\
(Y-1 \cdot)\end{array}$ \\
\hline$T / O V \pm \cdot / 9 V$ & $V / V r \pm r / q r$ & 10 & $r$ & امنيت شغلى & $r / \wedge 7 \pm 1 / \cdot 1$ & $\Lambda / 0 \pm r / .0$ & 10 & $r$ & 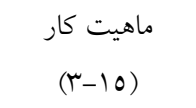 \\
\hline$r / Y Y \pm 1 / 1 \varepsilon$ & $q / \eta \perp \pm r / \varepsilon r$ & 10 & $r$ & ارتباط با سريرست & $r / 1 \cdot \pm \cdot / 9 r$ & $T / r T \pm r / \Lambda$. & 10 & $r$ & شناسايى \\
\hline $1 / 70 \pm \cdot / 9 \varepsilon$ & $\Gamma / \mu I \pm 1 / \Lambda \Lambda$ & 1. & r & حقوق و دستمزد & $T / V \wedge \pm 1 / 1$. & $\Lambda / r O \pm \Psi / r T$ & 10 & $r$ & رشد \\
\hline$r / 7 \cdot \pm 1 / \cdot 1$ & $O / T \cdot \pm T / I V$ & 1. & r & شرايط كارى & - & - & - & - & - \\
\hline$T / A V \pm \cdot / T V$ & $20 / 9 \Lambda \pm 1 \cdot / \wedge V$ & $u$ & 17 & 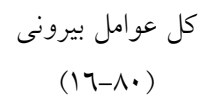 & $r / T T \pm \cdot / A r$ & $r 7 / 9 \cdot \pm 11 / 2$ & $7 r$ & $1 \varepsilon$ & 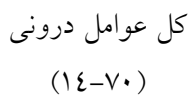 \\
\hline
\end{tabular}

بندى شده و در سه گروه افزايش انخيزه، كاهش انخيزه و

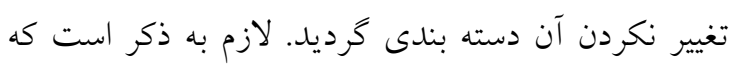
واحدهاى مورد يُزوهش، مى توانستند در ياسخ به اين سؤال

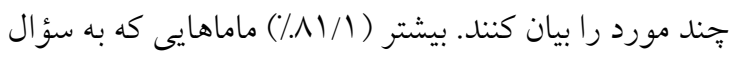
باز در مورد تغيير انخيزه شغلى (سؤال باز اول) جواب دادند

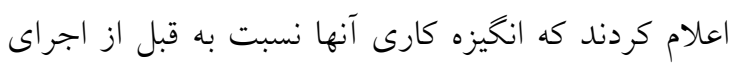
طرح تحول سلامت كمتر شده است. علل اين تغيير نيز طبق آناليز محتوى هدايت شده تجزيه و تحليل و در جدول

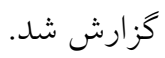

جدول شماره ب تغييرات انخيزه كارى نسبت به قبل از اجراى طرح تحول سلامت در ماماهاى مراقب سامت شاغل در بايشاه هاى سلامت زير مجموعه دانشخاه علوم يزشكى تهران در سال 9VI ا و علل آن را نشان مىدهد (سؤال باز اول). همان طور كه در اين جدول نشان داده شده است، از بين V.r شركت كننده در مطالعه، ع إ نقر قبل و بعد از طرح تحول سالامت سابقه كار داشتند. يعنى فقط عا1 نفر مىتوانستند به اين سؤال ياسخ دهند .از اين ميان 7· النفر به اين سؤال جواب دادهاند. (ميزان

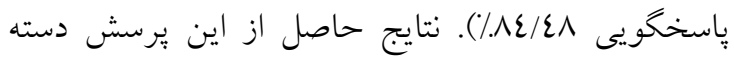


جدول شماره س: تغييرات انكَيزه كارى نسبت به قبل از اجراى طرح تحول سلامت در ماماهاى مراقب سلامت

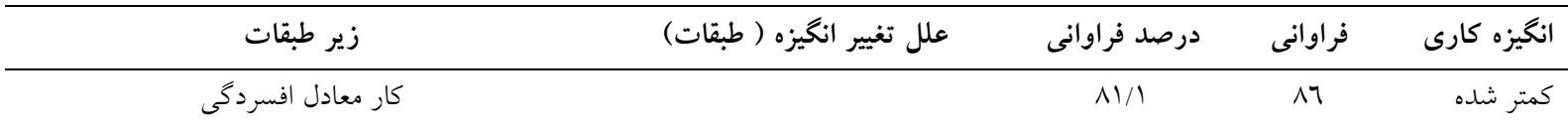

حداقل ارتباط با مددجو به دليل حجم كار زياد

شرح وظايف خارج از توان ماما

كار توان فرسا و فشار روانى بالا

فشار كارى زياد و رقابت پِرسنل در ارائه آمار بالا

\begin{tabular}{|c|c|c|c|c|}
\hline نداثند تيشك تمركز ماما در طرح تحول سار به علت تعدد وظايفت & "جند يِشكى و كاهش تمركز & & & \\
\hline 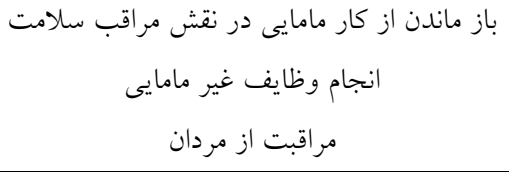 & كار غير مرتبط با مامايى & & & \\
\hline فقدان قدردانى باوجود كارت مدارزياد & ارزشيابى نامناسب از عملكرد & & & \\
\hline الكان ارائه خدمات و سيتمى شدن كار & كسب تجربه و به روز شدن & $11 / r$ & M & بيشتر شده \\
\hline & - & $V / 7$ & $\wedge$ & تغيير نكرده \\
\hline- & - & $1 \ldots$ & $1 \cdot 7$ & كل \\
\hline
\end{tabular}

جدول شماره ع: قصد ادامه كار به عنوان مراقب سلامت- ماما در ماماهاى مراقب سلامت

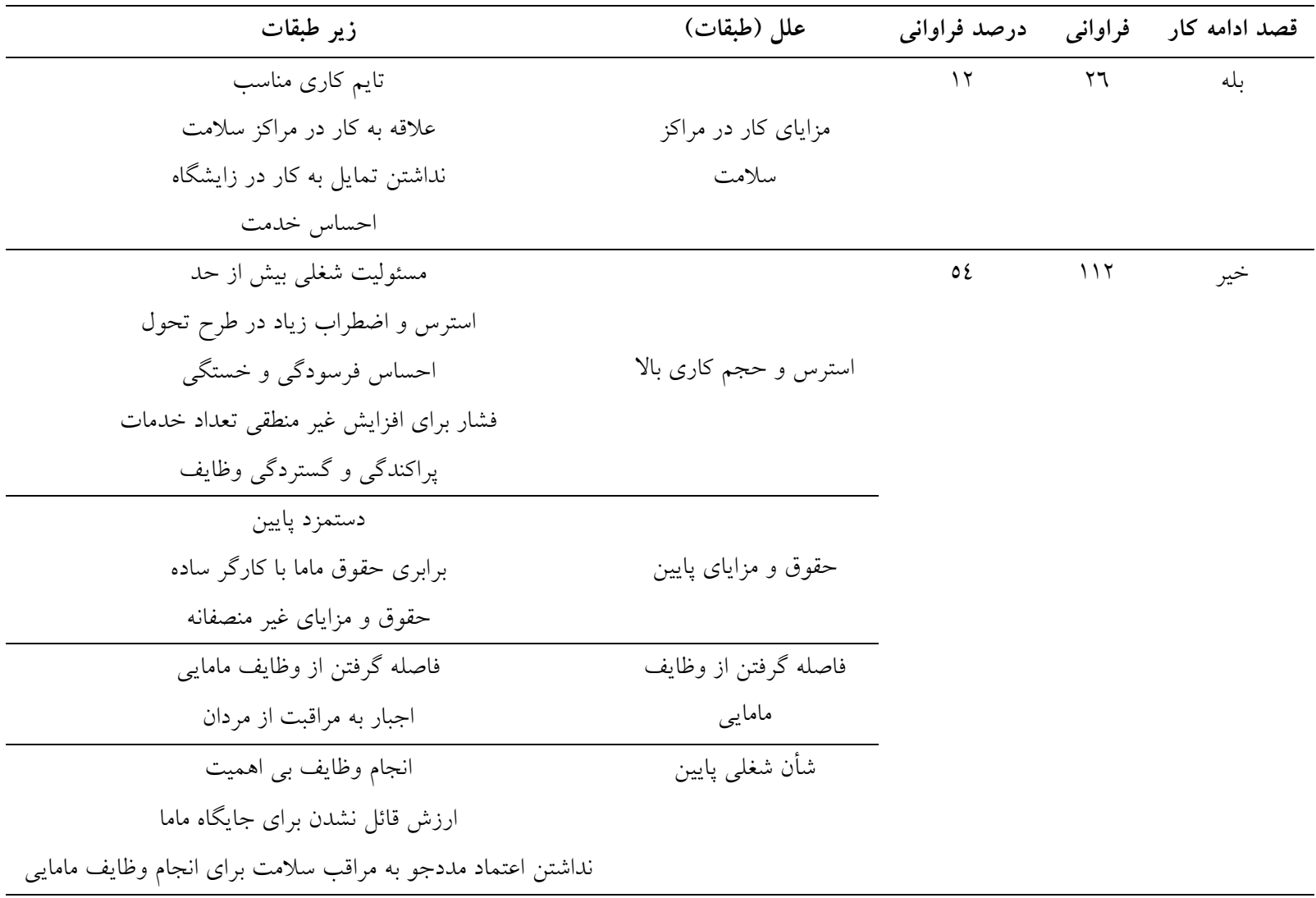




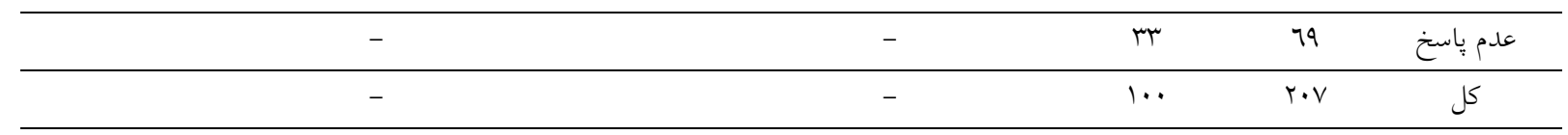

در مطالعه جودت و همكاران نيز در ميان عوامل درونى، حيطه شناسايى و قدردانى، كمترين امتياز را از نظر يرستاران

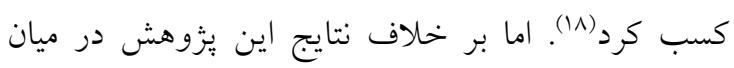

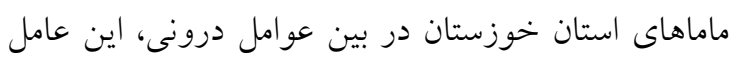

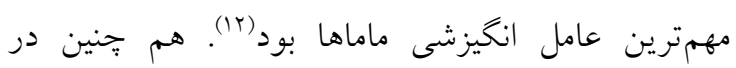

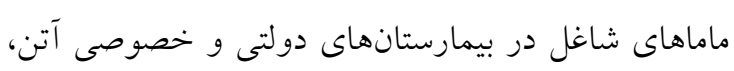

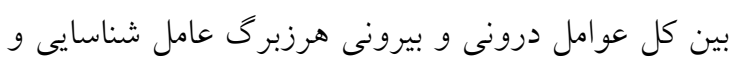

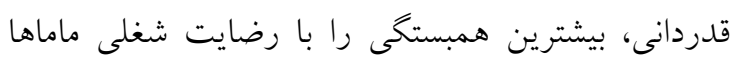

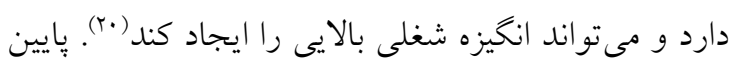
بودن امتياز عامل شناسايى در ماماهاى مر اقب سلامت بلد بدان

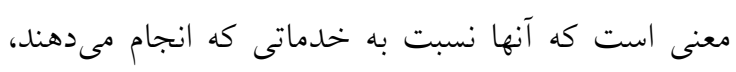

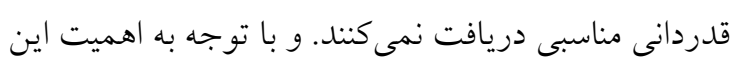

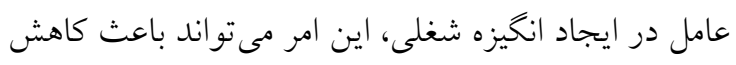

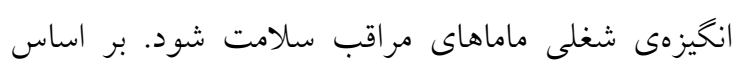

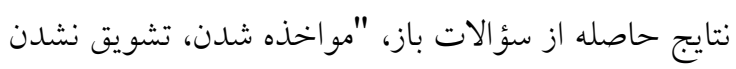

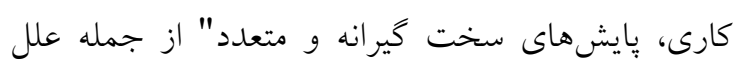

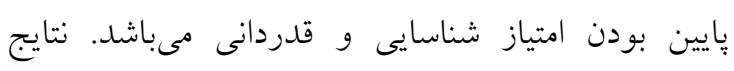
سؤالات باز نشان داد كه فقدان شناسايى و قدردانى علاوه

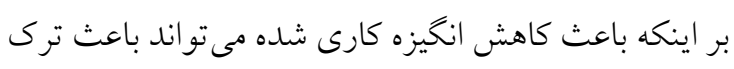

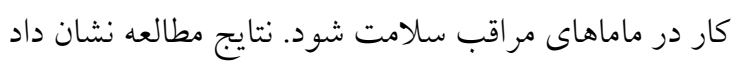
كه نارضايت شغلى و انخيزهى پايين با افزايش سابقه كار

$$
\text { بيشتر مى شود. }
$$

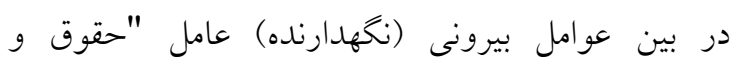

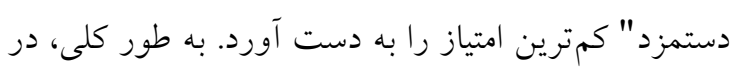

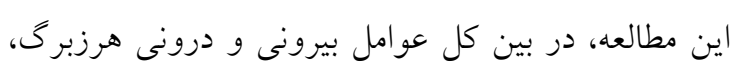

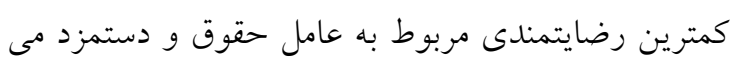

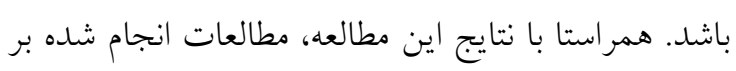
روى ماماهاى شاغل در واحدهاى زيرمجموعه دانشخاه

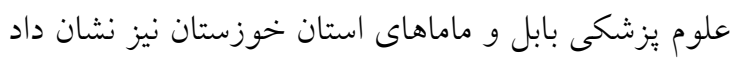

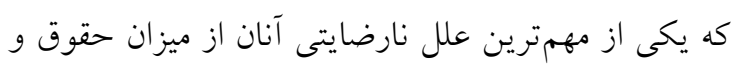

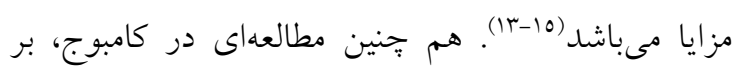

جدول شماره ع مربوط به قصد ادامه كاربه عنوان مراقب سلامت- ماما در ماماهاى مراقب سلامت شاغل در بايخاه

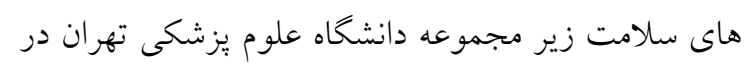

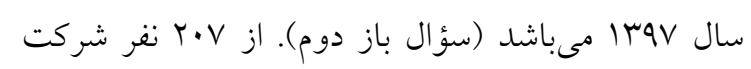

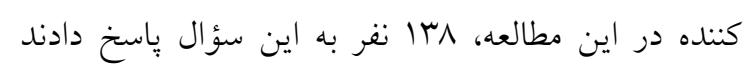

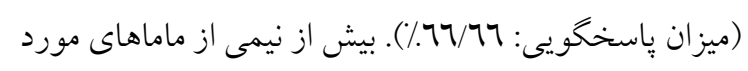

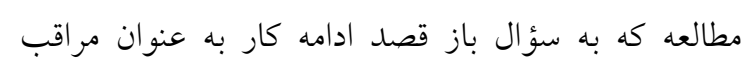
سلامت- ماما پِاسخ دادند، تمايل به ترى كار داشتند. دلايل

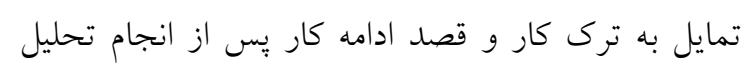
محتوى در جدول درج شده است.

\section{بحث و نتيجه تيرى}

نتايج مطالعه نشان داد كه در بين عو امل ديرى درونى (مؤثر بر

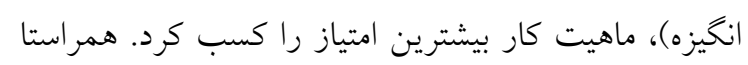
با نتايج يُزوهش حاضر دو مطالعه قبلى روى يرستاران بيمارستان در دزفول و اعضاى هيئت علمى در دانشخاه

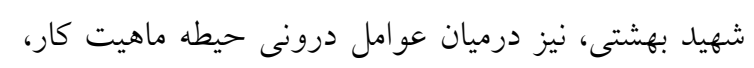

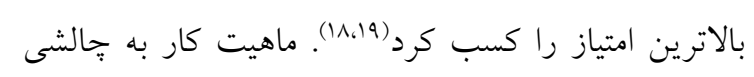
بودن، تنوع و يكنـواختى و به توانمندى فرد در انجام كار

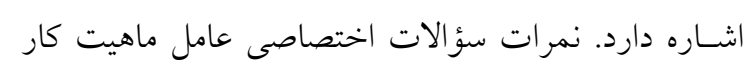

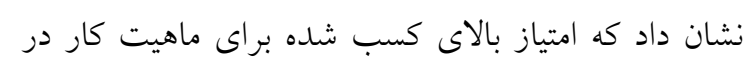

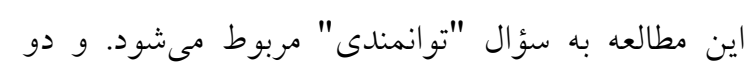

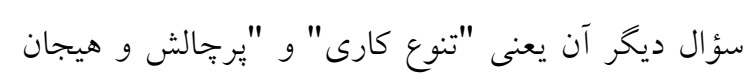

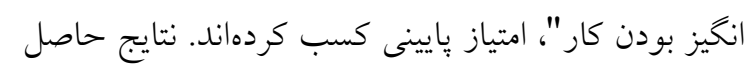

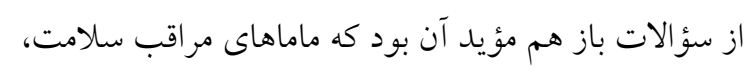
على رغم احساس تو انمندى در كار، به دليل وظايف كارى

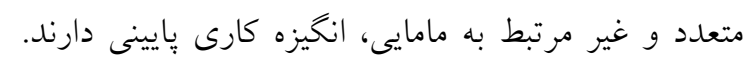
اين مسأله در بين ماماهاى رسمى بيشتر از بقيه ماماها ديده

هم تخين، ماماهاى مراقب سلامت در بين عوامل درونى، ״ايينترين رضايتمندى را از عامل تقدير و شناسايى دارند. 
مسئولين وزارت بهداشت و درمان به ايجاد تغييرات اساسى در مراكز بهداشتى درمانى در جهت افزايش رضايت شغلى بهانى ماماها مىباشد. در مورد ارتباط عوامل درونى (محرى انخيزه) با ويزگى ماند

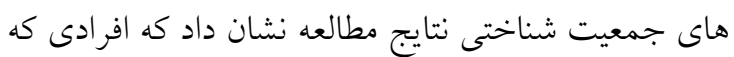
قبل از طرح تحول سلامت سابقه كار نداشتند و به واسطه

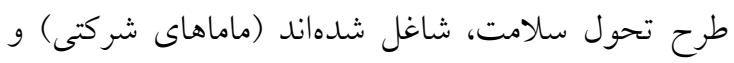

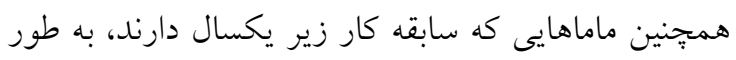
نسبى رضايت بيشترى از عوامل درونى نسبت به بقيه ماماها به دست آوردند. يعنى ماماهاى جديدالو الورود در ابتداى كار

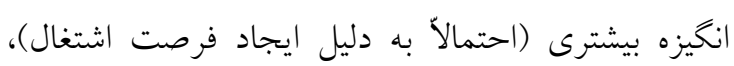

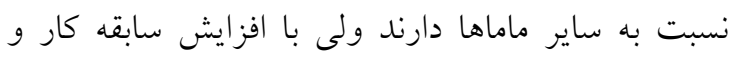
كسب تجربه كارى از ميزان انخيزه شغلى آنها كاسته شده

نتايج مطالعه در زمينه ارتباط عوامل بيرونى (عوامل

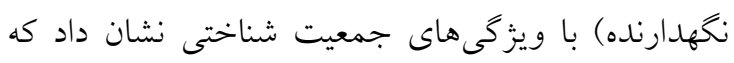

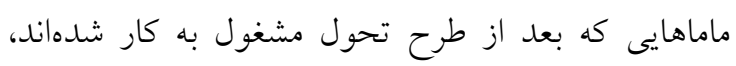

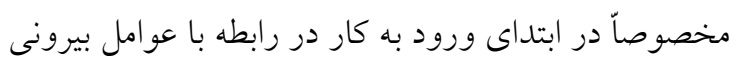

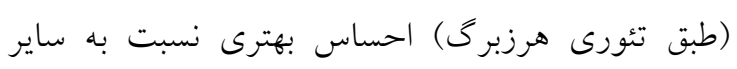

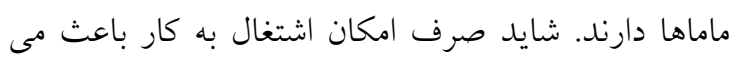
شود كه در وهله اول عوامل بيرونى حرفهى مراقب- ماما مارنا

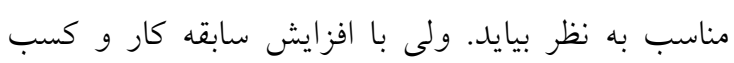
تجربه، رضايتمندى از عوامل بيرونى در بين همه ماماها كمتر مىشود. نتايج سؤالات باز نشان داد كه بيشتر بِاسخ دهندهها (1) درصد) انخيزهى كاريشان نسبت به قبل از طرح تحول كمتر شده است. در رابطه با علل كاهش انخيزه يس إن از آناليز

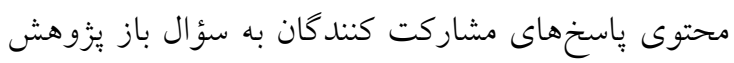

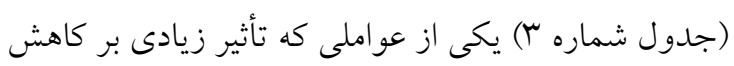

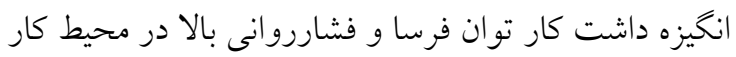

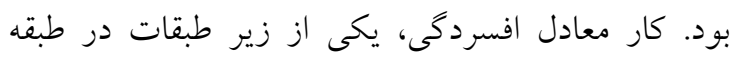

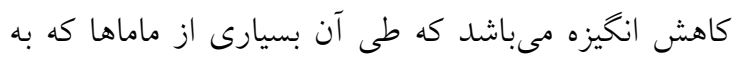

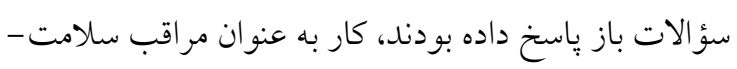

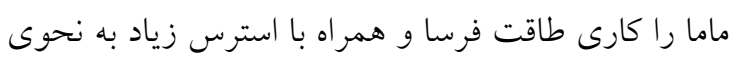

روى كاركنان نظام سلامت، نشان داد كه مشوقهاى مالى

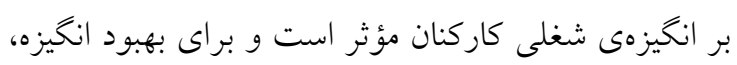

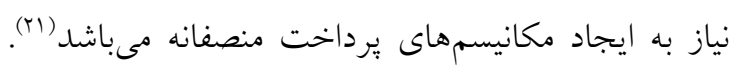

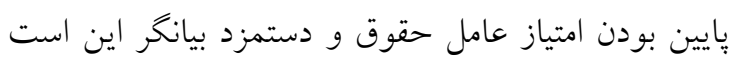

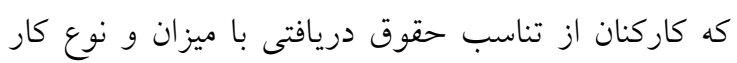
رضايت نداشتهاند. يس از اجراى طرح تحول در در مراكز

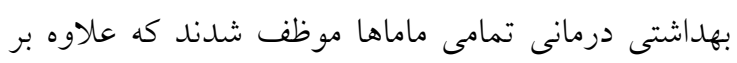

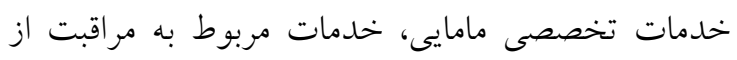

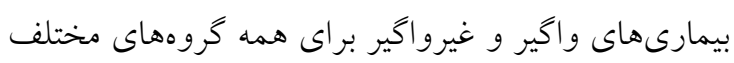

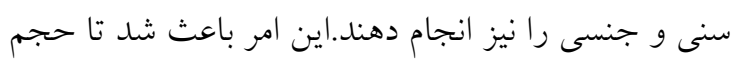

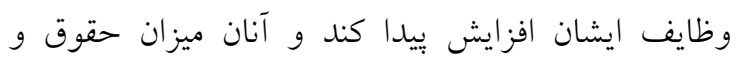

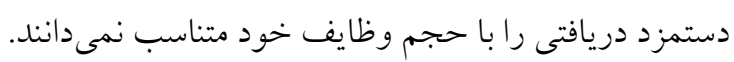

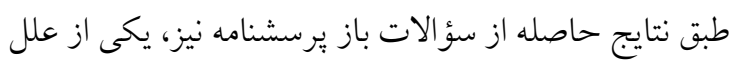

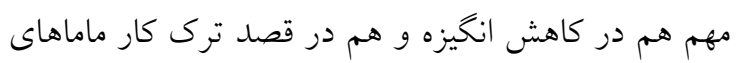

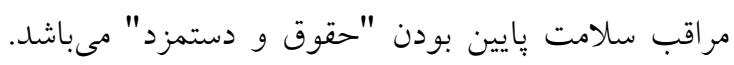

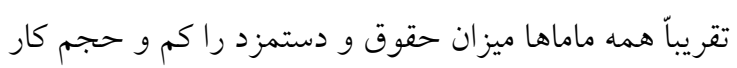
را زياد ارزيابى كردهاند. در بين عوامل بيرونى عامل "ارتباط با همكاران" بيشترين

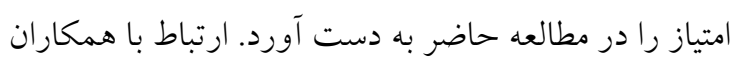

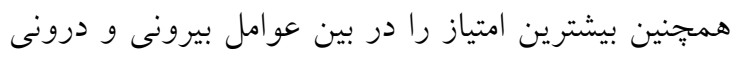

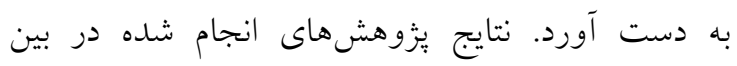

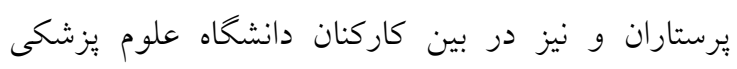

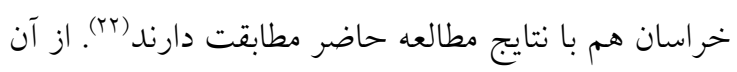

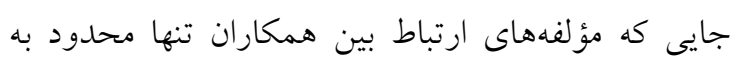
عوامل ادارى و سازمانى نيست لذا تحولات ادوات ادارى و تغيير

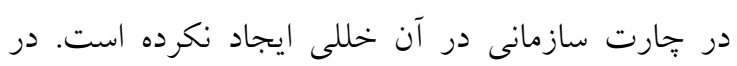

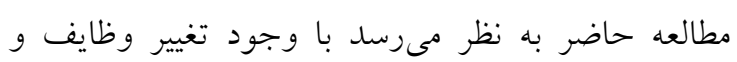

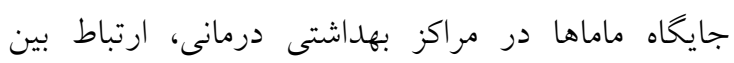
همكاران همجنان برايشان رضايت بخش است.

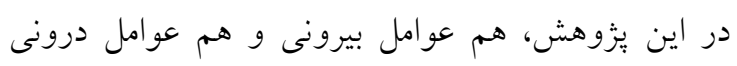

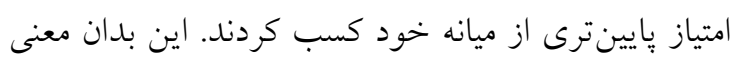
است كه ماماها رضايت بايينى از وضعيت كارى خود دارند.

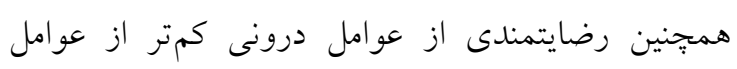

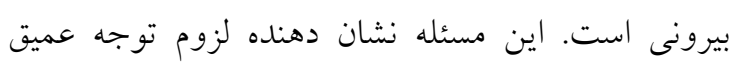


كار غير مرتبط با مامايى، يكى ديخر از زير طبقات كاهش

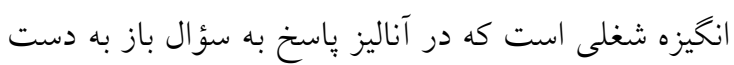

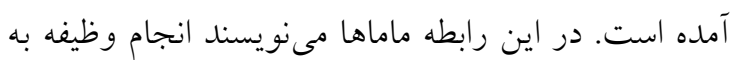
عنوان مراقب سلامت باعث شده تا آنان از وظايف مامايى

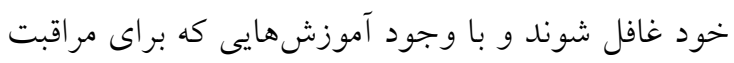

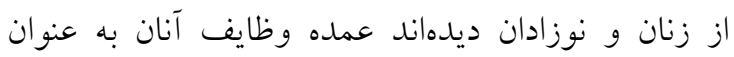
مراقب سلامت، مراقبت در زمينههاى غير مامايى و حتى مراقبت از مردان در زمينهايى غير از بهداشت بارورى مى في باشد. در اين رابطه مامايى با ·r سال سابقه كار مىنويسد:

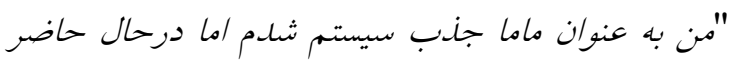
كمترين كارى كه انجام مىدهم مامايى هست. من ماما بايد مرقبتهاى مربوط به آقايان رو هم انجام بدم." منظور از مراقبت آقايان در اين كفتكو بررسى سلامت و صدور كواهى سلامت براى مشاغل مىباشد.

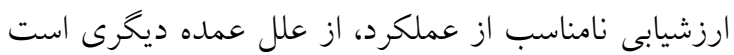

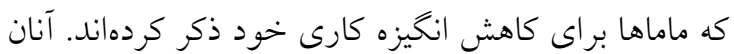
برخورد نامناسب ارزيابها، بازخواست مداوم و فقدان باندان قدردانى با وجود كار زياد را مصاديق ارزشيابى نامناسب باديب

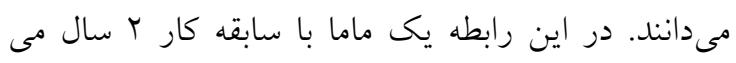

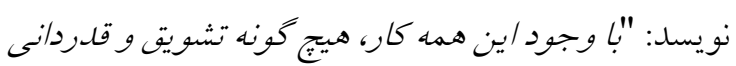
در كار نيست. به خاطر حتى يكى مشكل نمره كم مى كننا.

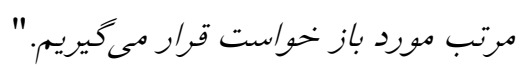

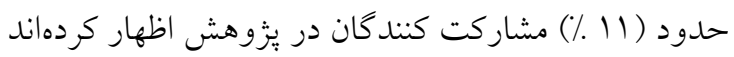

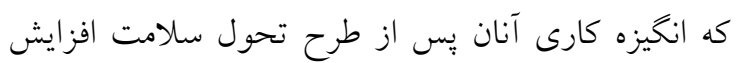

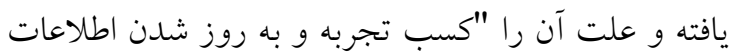

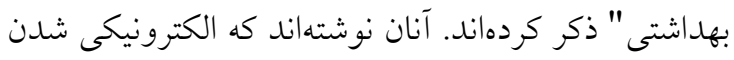
و به روز شدن سيستمها و امكان ارائه خدمات بيشتر به مردم را فراهم كرده. در همين زمينه مامايى با سابقه كار دو سال مى نويسد: 'الكترونيكى شان برونلههاى مراجعين و امكان نيى كيرى آنان باعث خلدمت بيشتر به مردم شله است." در بزوهش ديخرى در همين رابطه نيز همبستى عامل امكان بيشرفت شغلى با رضايت شغلى در ماماهاى شاغل در بيمارستان گزارش شده است (11).
كه منجر به افسردگى مى گردد اعلام كردند. در اين رابطه يكى از مشاركت كنند كان مىنويسد: "بار مسئوليت زياد،

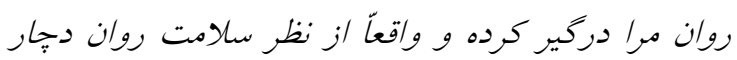

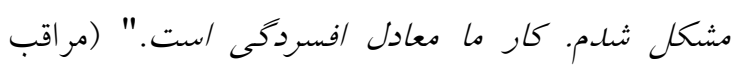

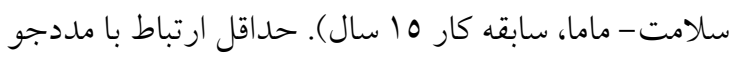
به دليل حجم كار زياد، شرح وظايف خارج از توان ماما،

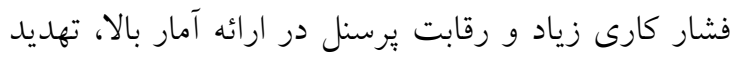
به كاهش دستمزد از علل ديخرى هستند كه موجب فشار روانى بالا و كاهش انخيزه كارى در ماماها شده است. در رابطه با حجم زياد كار، يك مر اقب سلامت- ماما با V سال سابقه كار مىنويسد: "انكيزه كار كم شاه خون حجم كارها يى كه در سامانه وجود داره خيلى زياده به طورى كه

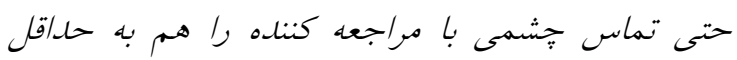
رسانده." يا مشاركت كننده ديخرى با ع سال سابقه كار در لهر

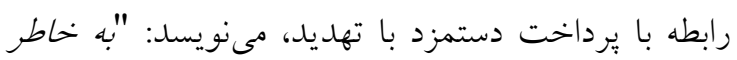
خدمت كم، حقوق كم مىشود و حقوق با تهلديد به ما

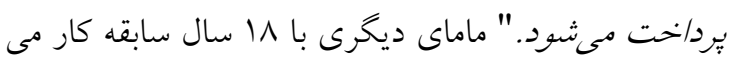

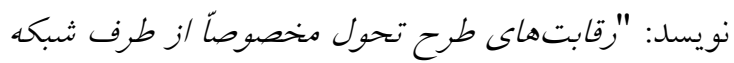

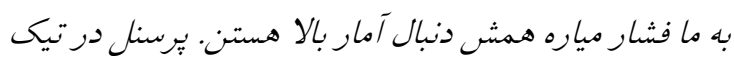

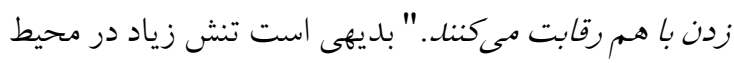

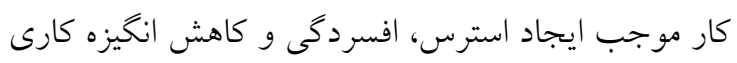

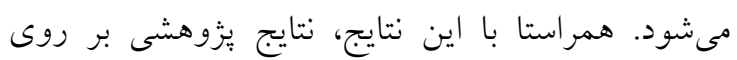

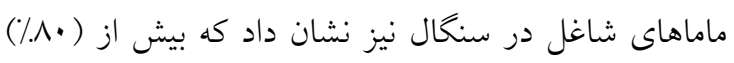

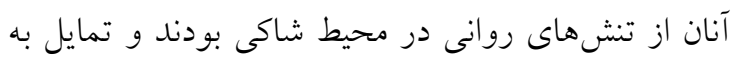
ترى كار داشتند (·).

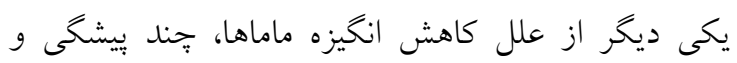
كاهش تمركز مىباشد. در اين رابطه ماماها از تعدد وظايف و نداشتن تمركز ناراضى بودند به طورى كه مشاركت كننده

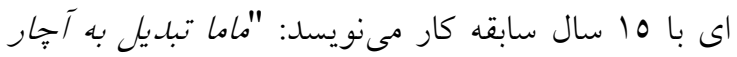

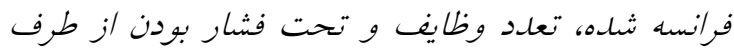

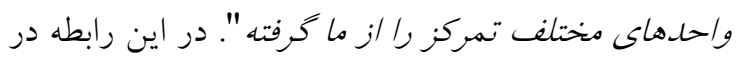
يزوهشى بر روى ماماهاى شاغل در تركيه نيز نارضايتى از محيط كارى از عمدهترين مشكلات ماماهاى شاغل در مراكز بهداشتى تركيه بود (11). 
تواند باعث ترى كار در ماماها شود. بر اساس تئورى دو

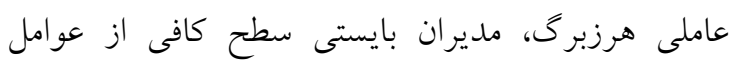
بيرونى (بهداشتى) را در اختيار كارمندان قرار دهند تا آنها

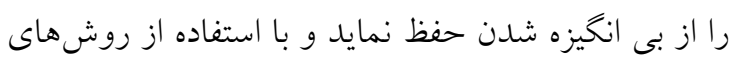
ارتقاء دهنده عوامل درونى مانند غنى سازى شغلى انى انخيزه شغلى را ارتقاء دهند. از اين رو ييشنهاد مى شود مسئولين

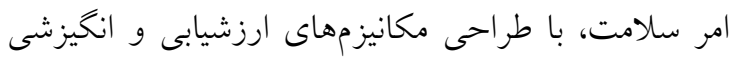

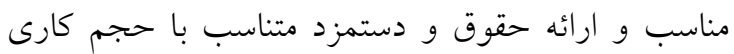
(ارتقاء سطح عوامل بيرونى) و با تعريف جايكاه شغلى ماماى خانو اده در نظام سلامت به جاى مراقب سلامت و بازنخرى اساسى در شرح وظايف و جايخاه مامايى در

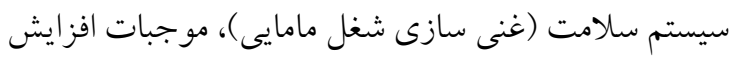
انخيزهى شغلى ماماها و در نتيجه حفظ و ارتقاى كيفيت

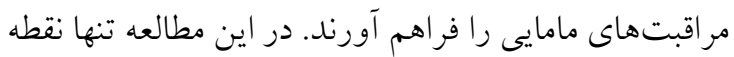
نظر ات ماماهاى مراقب سلا مت بررسى شده است و به نظر

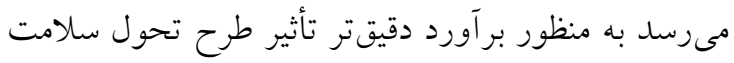

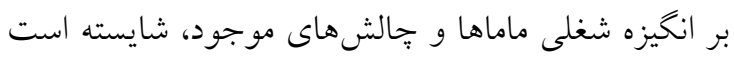
تا نظرات مديران ميانى و مسئولين طرح نيز در اين مورد برسى گردد.

تعارض منافع: هيج كونه تعارض منافع توسط نويسندگان بيان نشده است.

\section{تقدير و تشكر}

اين يززوهش حاصل بايان نامه مقطع كارشناسى ارشد مامايى

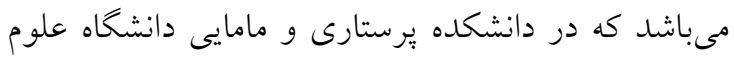
يزشكى تهران مصوب شده است. محققين بر خود لازم

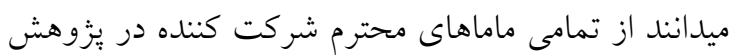

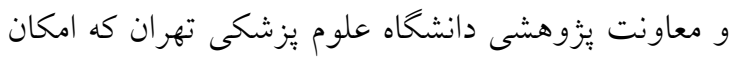
انجام اين مطالعه را فراهم كردند تشكر نمايند.
در پِاسخ به سؤال باز مبنى بر قصد ادامه كار يا ترك شغل،

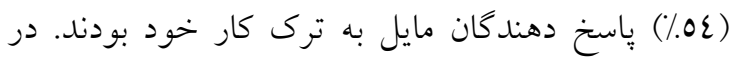
آناليز پِاسخهاى درج شده در اين سؤال، مانند سؤال باز قبلى عو املى همجيون: استرس و حجم كارى بالا، حقوق و مزاياى يايين، فاصله كَرفتن از وظايف مامايى ذكر شده

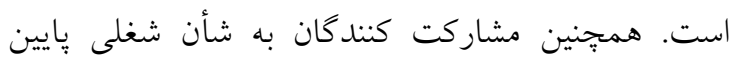
ماماها در مر اكز بهاشتتى درمانى اشاره كردهاند از نظر آنان در طرح تحول سلامت تغيير جايخاه شغلى ماماها از ماما به مراقب سلامت باعث شده تا وظايف آنان در حد يذيرش مددجويان كه قبلاّ وظيفه منشى مركز بوده است نزول كند و احترام و جايكاه شغلى آنان حفظ نشود. در اين رابطه مامايى با IV سال سابقه كار مىنويسد: "عنوان مراقب

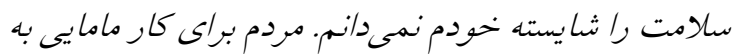

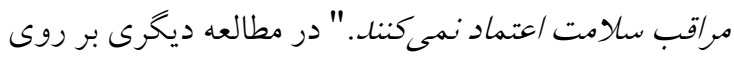
ماماهاى شاغل در مراكز بهداشتى درمانى نيز ارتباط معكوسى بين ابهام در وظايف شغلى و رضايت شغلى ديده

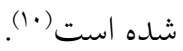

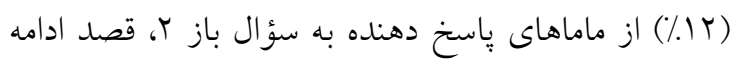

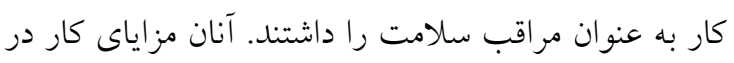

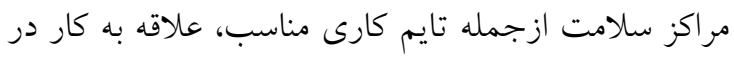

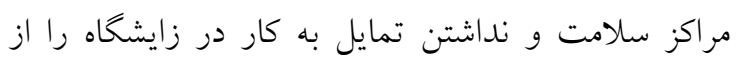

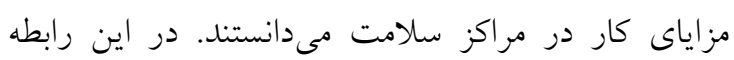

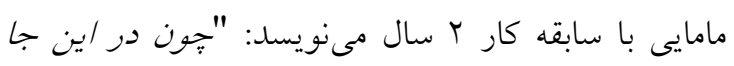

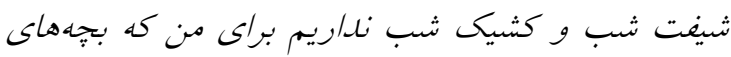

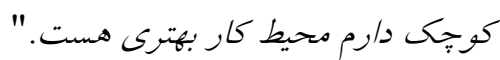
با توجه به يافتهاى اين مطالعه وظايف كارى متعدد و غير مرتبط به مامايى، استرس و حجم بالاى كار، حقوق و دستمزد پايين و قدردانى نامناسب باعث كاهش انخيزه كارى در ماماهاى مراقب سلامت شده است. نتايج نشان

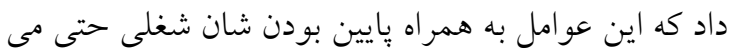

\section{References}

1. Hakimi S. A century (1919-2019) of academic midwifery in Iran: From traditional midwives to PhD graduates. Eur J Midwifery. 2019;3(June):11

2. Mahmoudi H, Ebrahimian A, Solymani M, Ebadi A, Hafezi S, Fayzi F, Sadeghi M. The study of job motivation factors in critical care nurses. Journal of Behavioral Sciences. 2007;1(2):171-8. [Persian] 
3. Doshmangir L, Bazyar M, Majdzadeh R, Takian A. So near, so far: four decades of health policy reforms in Iran, achievements and challenges. Archives of Iranian medicine. 2019;22(10):592-605. [Persian]

4. UNFPA. International day of the midwife. Available at: https://eeca.unfpa.org/en/node/6579. Accessed May 5, 2016.

5. Rezaeian A. Fundamentals of organizational behavior management. The Organization for Researching and Composing University textbooks in the Humanities or SAMT. 2016:385-405. [Persian]

6. Bessell I, Dicks B, Wysocki A, Kepner K. Understanding motivation: an effective tool for managers. University of Florida Institute of Food and Agricultural Sciences. 2012.

7. Abbaschian R, Avazeh A, Rabi SiahkaliS S. Job satisfaction and its related factors among nurses in the Public Hospitals of Zanjan University of Medical Sciences, 2010. Preventive Care in Nursing \& Midwifery Journal. 2011;1(1):17-24. [Persian]

8. Khademi ZH, Fakhrzad MB, Akrami MK. Prioritizing Motivating Factors to Increase Staff Productivity (Case Study: Fars Oil Distribution Company). Human Resource Management In The Oil Industry. 2011;4(13):85- 104. [Persian]

9. Rahimparvar SF, Nasiriani L, Khoda TF, Azimi K, Bahrani N. Job Satisfaction and Some of Its Related Factors in Midwives of Tehran Health Centers. Iranian Red Crescent Medical Journal. 2017;19(3). [Persian]

10. Rouleau D, Fournier P, Philibert A, Mbengue B, Dumont A. The effects of midwives' job satisfaction on burnout, intention to quit and turnover: a longitudinal study in Senegal. Human resources for health. 2012;10(1):1-4.

11. Uçuk SU, Güler HA. Job Satisfaction Levels in Midwifery. Int J Human Social Scie Inven 2016;5(6), 53-60

12. Keshtkar Rajabi M, Etebarian AA. The study and philosophical critique of Frederick Herzberg's two-factor theory from a symbolic-interpretative viewpoint. Management Studies in Development and Evolution. 2018;27(89):119-44. [Persian]

13. Khavayet F, Tahery N, Alizadeh Ahvazi M, Tabnak A. A Survey of job satisfaction among midwives working in hospitals. Journal of Midwifery and Reproductive Health. 2018;6(1):118692. [Persian]

14. Outofi A, Kharazmi E, Yousefi A, Heidari A. The comparative study of hygiene-motivational factors based on Herzberg theory among Faghihi and Kossar Shiraz hospitals staffs in 2011. Journal of Hospital. 2014;13(2):97-104. [Persian]

15. Hedayati A, Pourmajidian T. Improving performance by increasing job motivation among midwives in Babol University of Medical Sciences. Caspian Journal of Reproductive Medicine. 2016 10;2(1):13-9. [Persian]

16. Kheirkhah M, Masrour MJ, Sefidi M, Jalal EJ. The relationship between job motivation and its dimensions with organizational commitment and its dimensions in midwives of sanitary and therapeutic centers, Arak University of Medical Sciences, 2017. J Fam Med Prim Care. 2018;7(2):368-373.

17. Hsieh HF, Shannon SE. Three approaches to qualitative content analysis. Qual Health Res. 2005;15(9):1277-88.

18. Jodat S, Farajzadeh Z, Saadatjoo SA. A study of job motivation of nurses working in Valiasr Hospital of Birjand in 2013. Modern Care Journal. 2013;10(4). [Persian]

19. Ziar S, Momtazmanesh N, Ahmadi S, Abdi AR, Ahmadi F. Effective Factors in Job Motivation of Faculty Members of Shaheed Beheshti University of Medical Sciences Based on Herzbergl's TwoFactor Theory of Motivation in 1394. Journal of Medical Education Development. 2016;9(23):2030. [Persian]

20. Papoutsis D, Labiris G, Niakas D. Midwives' job satisfaction and its main determinants: A survey of midwifery practice in Greece. Bri J Midwif. 2014;22(7):480-6.

21. Khim K. Are health workers motivated by income? Job motivation of Cambodian primary health workers implementing performance-based financing. Glob Health Act. 2016;9(1):31068.

22. Sadeghi A, Darzi RS, Toroski M, Emami O, Heydari G, Shahraki H. Viewpoints of the staff of North Khorasan University of Medical Sciences about the motivational and hygiene factors affecting their performance and satisfaction.. Sadra Medical Sciences Journal. 2014;2(2):111-21. [Persian] 